\title{
Nucleophilic addition to an achiral dehydroalanine Schiff base Ni(II) complex as a route to amino acids. A case of stereodetermining asymmetric protonation in the presence of TADDOL
}

\author{
Yuri N. Belokon, ${ }^{*},{ }^{a}$ Syuzanna Harutyunyan, ${ }^{a}$ Evgeni V. Vorontsov, ${ }^{a}$ \\ Alexander S. Peregudov, ${ }^{a}$ Viktor N. Chrustalev, ${ }^{a}$ Konstantin A. Kochetkov, ${ }^{a}$ \\ Dmitriy Pripadchev, ${ }^{a}$ Ashot S. Sagyan, ${ }^{b}$ Albert K. Beck, ${ }^{c}$ and Dieter Seebach* ${ }^{*}$ \\ ${ }^{a}$ A.N. Nesmeyanov Institute of Organo-Element Compounds, Russian Academy of Sciences, \\ 119991, Moscow, Vavilov 28, Russian Federation, Department of Chemistry. ${ }^{b}$ Department of \\ Chemistry, Yerevan State University, Manukyan 1, Yerevan, Armenia \\ E-mail:yubel@ineos.ac.ru \\ ${ }^{c}$ Laboratorium für Organishe Chemie der Eidgenössischen Technishen Hochschule, ETH- \\ Hönggerberg, Wolfgang-Pauli-Strasse 10, CH-80903, Zürich, Switzerland \\ E-mail:seebach@org.chem.ethz.ch
}

Dedicated to Professor Mieczyslaw Makosza on his $\mathbf{7 0}^{\text {th }}$ birthday

(received 31 Jul 03; accepted 13 Jan 04; published on the web 30 Jan 04)

\begin{abstract}
We describe herein the elaboration of a new type of a substrate based on the Ni(II) complex of a Schiff base of dehydroalanine, $\mathbf{1}$, and Michael addition of nucleophiles to it, leading to the synthesis of racemic $\alpha$-amino acids. We have also developed a catalytic method for the asymmetric 1,4 conjugate addition of achiral $\mathrm{CH}$-acids to $\mathbf{1}$ promoted by TADDOLs with enantioselective catalytic protonation of the intermediate enolate in the stereodetermining stage of the reaction. A sizable $80 \%$ ee of the product was observed.
\end{abstract}

Keywords: Michael addition, amino acid, asymmetric protonation, TADDOL

\section{Introduction}

Enantioselective conjugate addition is a fundamentally important transformation in asymmetric synthesis. ${ }^{1}$ The asymmetric catalytic version of the reaction was used for amino acid synthesis with remarkable success, applying condensation of O'Donnel's glycine imine derivatives and acrylic acid esters catalyzed by Cinchona alkaloid ammonium salts and synthetic quaternary ammonium salts as efficient chiral phase-transfer catalysts. ${ }^{2}$ It is generally assumed that the stereoselective formation of the $\mathrm{C}-\mathrm{C}$ bonds and consequently of the amino acid occur at the stage of the addition of the intermediate enolate of the glycine derivative to the activated $\mathrm{C}=\mathrm{C}$ bond of acrylic derivatives 
within the ion pair formed by Cinchona alkaloid ammonium salt and the enolate. ${ }^{3}$ Another possibility of introducing asymmetry into the adduct by enantioselective catalytic protonation of the intermediate enolate was generally neglected. To the best of our knowledge only a few papers have been published on the subject of asymmetric catalytic $\mathrm{C}-\mathrm{H}$ bond formation without a preceding enantioselective C-C-bond-forming step in the Michael addition. ${ }^{4}$

In recent years intense research efforts have been directed towards studying enantioselective protonation of enolates by chiral acids. ${ }^{5}$ One of the possibilities is the protonation of a complex formed between an enolate and a chiral ligand with an achiral proton source. ${ }^{6}$ Recently, Guenca et al. have found that TADDOL ( $\alpha, \alpha, \alpha^{\prime}, \alpha^{\prime}$-tetraaryl-1,3-dioxalan-4,5-dimethanol) can serve as an efficient chiral proton source and affected highly enantioselective stoichiometric protonation of some Li-enolates. ${ }^{7}$ On the other hand Belokon et al. have found that alkali metal TADDOLates functioned as efficient catalytic hydrophobic bases in asymmetric $\mathrm{C}$-alkylation of $\mathrm{CH}$ - acids with alkyl halides. ${ }^{8}$

We describe herein the elaboration of a new type of a substrate based on the Ni(II) complex of a Schiff's base of dehydroalanine, $\mathbf{1}$, and Michael-type addition of nucleophiles occur leading to racemic $\alpha$-amino acids. We have also attempted to develop a catalytic variation for the asymmetric 1,4 conjugate addition of achiral $\mathrm{CH}$-acids to $\mathbf{1}$ promoted by TADDOLs with asymmetric catalytic protonation of the intermediate enolate in the sterodetermining stage of the reaction.

\section{Results and Discussion}

The achiral complex 1 was derived from the Ni(II) complex of the Schiff's base of glycine and PBP (pyridine-2-carboxylic acid (2-benzoyl-phenyl)-amide) ${ }^{9} \mathbf{2}$, which was converted into the serine derivative 3, followed by dehydration in acetic anhydride/ $\mathrm{Na}_{2} \mathrm{CO}_{3}$ system (Scheme 1, overall yield $84 \%)$. A great advantage of $\mathbf{1}$ is its high crystallinity and stability, as compared to known analogs of dehydroalanine, ${ }^{10 a-d}$ as well as its red color, making TLC monitoring of the reactions easy.

The substrate 1 proved to be very convenient for the synthesis of racemic $\alpha$-amino acids by Michael addition of nucleophiles in analogy with an earlier described procedure for the synthesis of non-racemic amino acids, using chiral Ni(II) dehydroalanine Schiff base complexes with BPB. ${ }^{10 e, f}$ The reaction of 1 with nucleophiles was carried out according to Scheme 2, and the course of the reaction was monitored by $\mathrm{TLC}\left(\mathrm{SiO}_{2}, \mathrm{CHCl}_{3} /\right.$ acetone). After completion, the reaction mixture was neutralized and the red solid residue purified either by chromatography or by crystallization. The crystal structure of the product of malonic ester addition to $\mathbf{1}$ is shown in Figure 1. The decomposition of the final complexes was effected by dilute aqueous $\mathrm{MeOH} / \mathrm{HCl}$ within $5-60$ minutes, with heating under reflux. The process was easily followed by the change of the solution color from red to blue. Insoluble hydrochloride of PBP is removed by filtration in almost quantitative yield, and $\mathrm{NiCl}_{2}$ and the amino acid are easily separated by ion exchange chromatography or by using EDTA (see experimental part). 


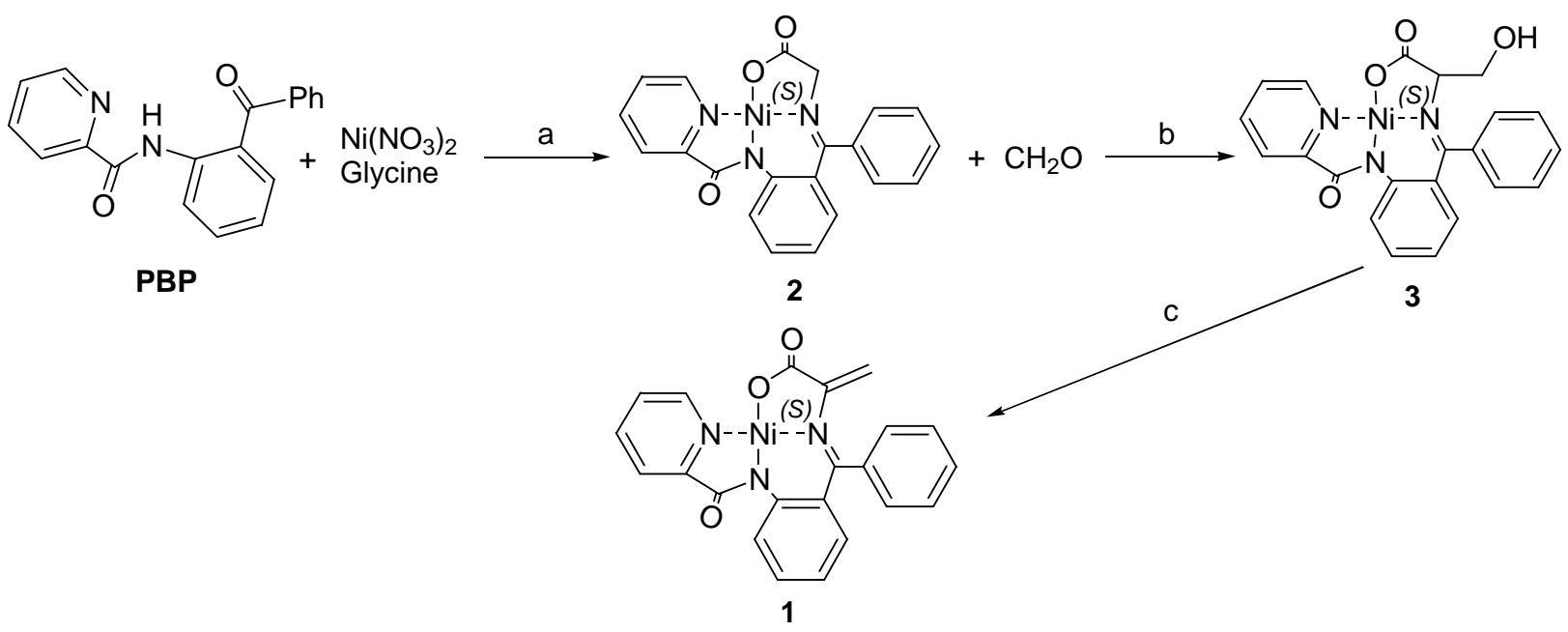

(a) $\mathrm{MeONa}, \mathrm{MeOH}$, reflux, 20min. (b) $\mathrm{MeONa}, \mathrm{MeOH}$, reflux, 1h. (c) $\mathrm{Ac}_{2} \mathrm{O}, \mathrm{Na}_{2} \mathrm{CO}_{3}, \mathrm{CH}_{3} \mathrm{CN}$, reflux, 5 .

Scheme 1. Synthesis of substrate 1.
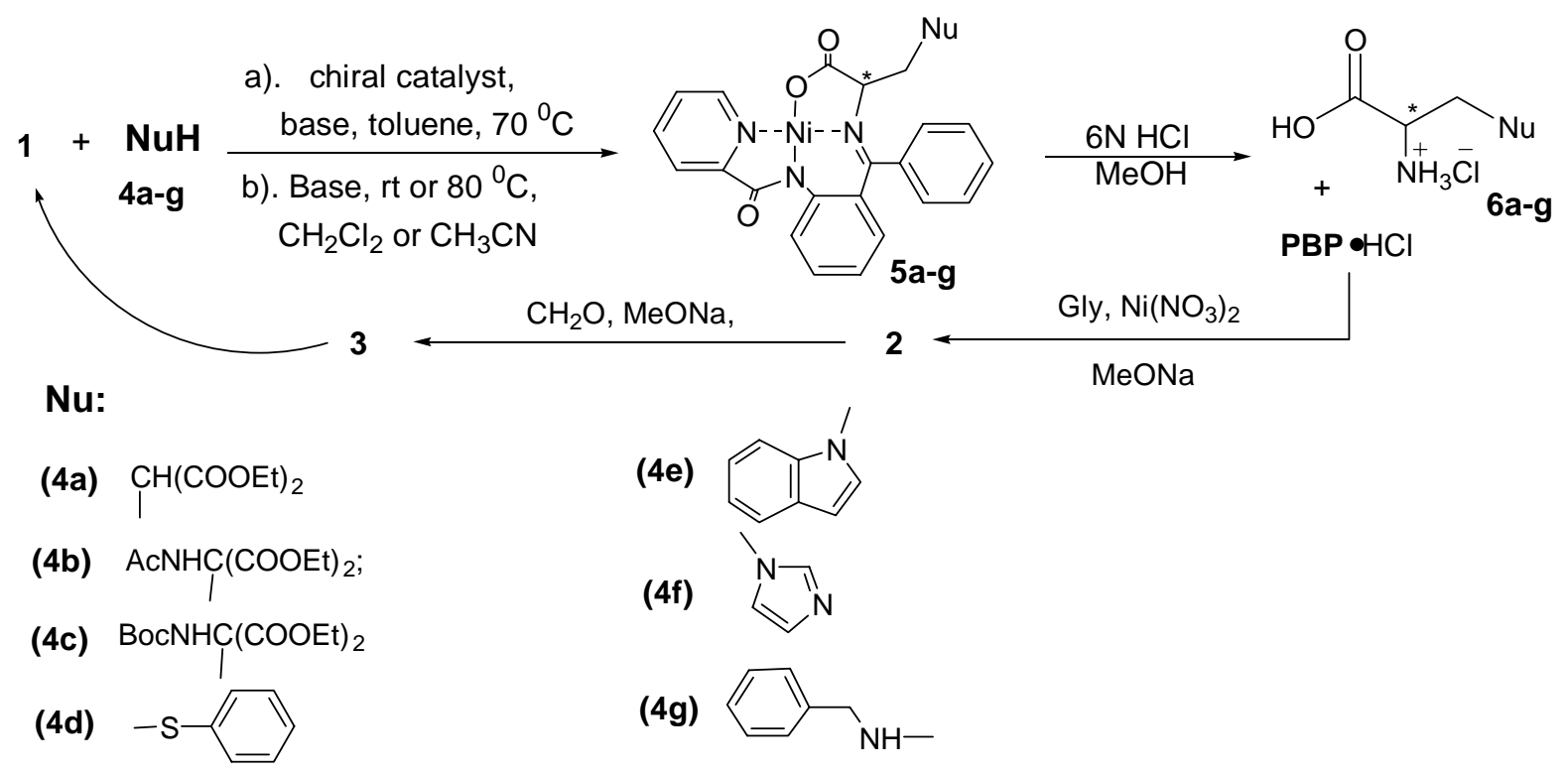

(4e)

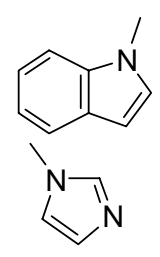

(4g)

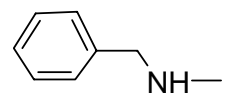

Scheme 2. Michael addition of various nucleophiles $\mathbf{4}$ to substrate $\mathbf{1}$.

All results of Michael additions of nucleophiles $\mathbf{4 a - g}$ are presented in Table 1. The addition of 4a proceeded without any catalyst in the presence of bases in $\mathrm{CH}_{2} \mathrm{Cl}_{2}$ and gave complex $\mathbf{5 a}$ in high yield (Table1, run 1). Racemic glutamic acid could be recovered from the complex after hydrolysis. 


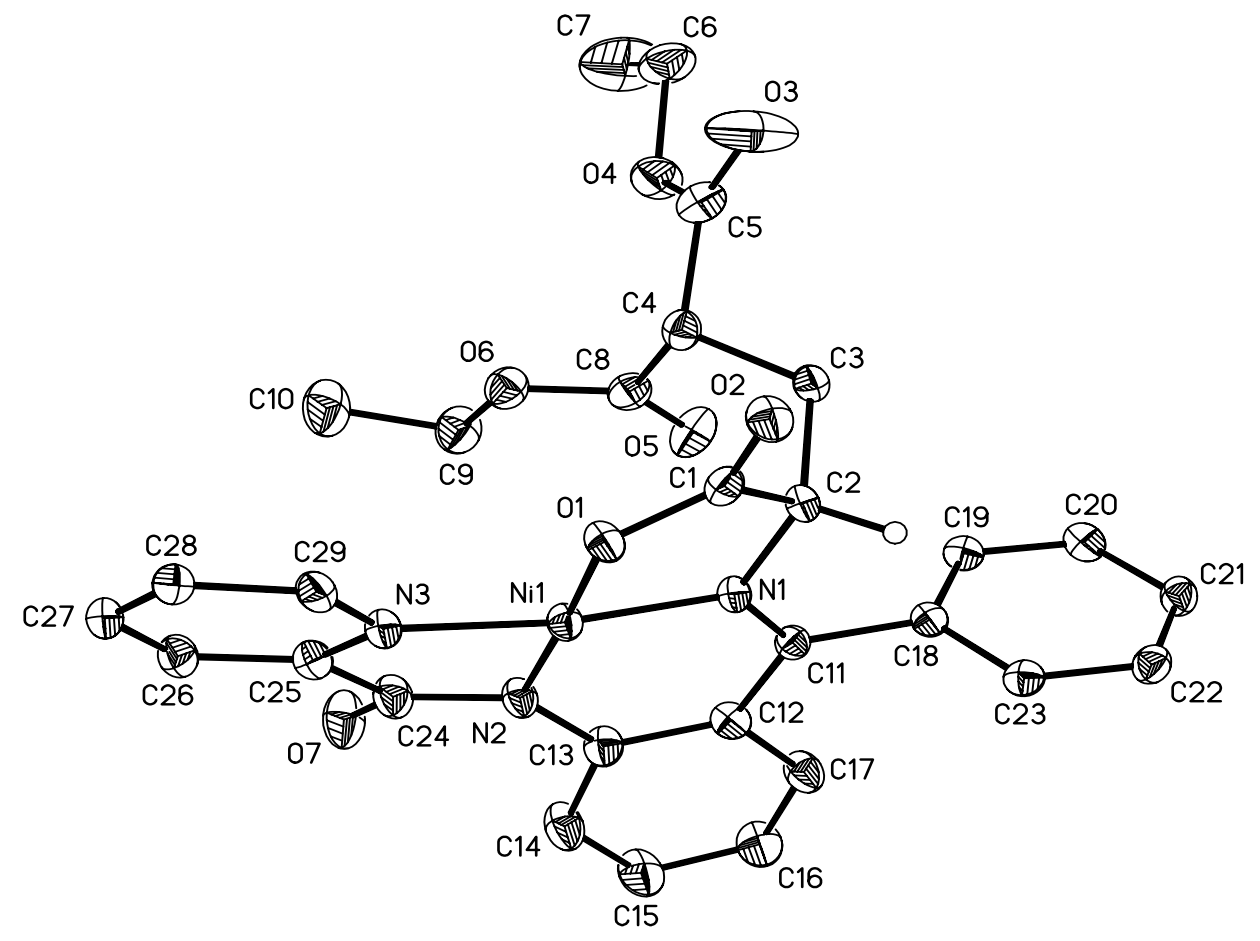

Figure 1. Structure of the complex 5a.

Table 1. Reaction of the complex 1 with different types of nucleophiles in the presence of $\mathrm{NaH}$ under conditions $b$ of Scheme 2

\begin{tabular}{|c|c|c|c|c|c|}
\hline Run $^{\mathrm{a}}$ & $\mathrm{NuH}^{\mathrm{b}}, 4$ & $( \pm)-5$ & $\begin{array}{c}\text { Solvent/ Temp } \\
{\left[{ }^{0} \mathrm{C}\right]}\end{array}$ & $\begin{array}{l}\text { Time } \\
{[\mathrm{min}]}\end{array}$ & $\begin{array}{c}\text { Yield } \\
{[\%]}\end{array}$ \\
\hline 1 & $\mathrm{CH}_{2}(\mathrm{COOEt})_{2}$ & $\mathbf{a}$ & $\mathrm{CH}_{2} \mathrm{Cl}_{2} /[20]$ & 10 & $85^{c}$ \\
\hline 2 & $\mathrm{PhSH}$ & d & $\mathrm{CH}_{2} \mathrm{Cl}_{2} /[20]$ & 25 & $75^{\mathrm{c}}$ \\
\hline 3 & & $\mathbf{e}$ & $\mathrm{CH}_{3} \mathrm{CN} /[80]$ & 180 & $80^{\mathrm{d}}$ \\
\hline 4 & & f & $\mathrm{CH}_{3} \mathrm{CN} /[80]$ & 90 & $88^{\mathrm{e}}$ \\
\hline 5 & & g & $\mathrm{CH}_{2} \mathrm{Cl}_{2} /[20]$ & 60 & 58 \\
\hline 6 & & g & $\mathrm{iPrOH} /[80]$ & 15 & $56^{\mathrm{e}, \mathrm{f}}$ \\
\hline 7 & & $\mathbf{g}$ & $t \mathrm{BuOH} /[80]$ & 15 & $70^{\mathrm{e}, \mathrm{f}}$ \\
\hline
\end{tabular}

${ }^{\mathrm{a}}$ Concentration of the substrate $0.23 \mathrm{M} .{ }^{\mathrm{b}} 10-50 \mathrm{~mol} \%$ of $\mathrm{NaH}$ was employed (see experiment). ${ }^{\mathrm{c}}$ Ratio 4/1 was $3 .{ }^{\mathrm{d}}$ Ratio of $\mathbf{4 / 1}$ was 1.2 . ${ }^{\mathrm{e}}$ Ratio of $\mathbf{4 / 1}$ was $2{ }^{\mathrm{f}}$ The reaction was carried out without $\mathrm{NaH}$. 
The reactions with thiophenol and benzylamine occurred readily to give the corresponding complexes $\mathbf{5 d}$ and $\mathbf{5 g}$ in good chemical yields (Table 1, run 2, 5). The absence of any absorption in the region of $2500-2650 \mathrm{~cm}^{-1}$ for $\mathbf{5 d}$ proved that the addition for thiophenol occurred via its sulfur atom, as usual, and shown earlier for a similar addition to a chiral analogue of $1{ }^{10 \mathrm{e}}$ Less active nucleophiles such as indole and imidazole required harsher reaction conditions $\left(\mathrm{CH}_{3} \mathrm{CN}\right.$ at reflux temperature for several hours, Table 1 run 3,4 ) leading to the corresponding racemic complexes 5e,f. Analyses of the structures of complexes $\mathbf{5 e , f}$ by IR and NMR spectroscopy showed that the addition of imidazol and indol both occurred via formation of $\mathrm{N}-\mathrm{C}$ bonds. Comparison of the chromatographic behavior of samples of the amino acids with samples of histidine and tryptophane is compatible with this conclusion.

An attempt with phenol failed: no product of addition to $\mathbf{1}$ was detected. Still a new product was formed in 25\% yield: meso-compound $\mathbf{5 i}$ as proved by NMR spectroscopy (see experiment) and Xray single-crystal analysis (Figure 2). Apparently, the reaction proceeded as described in Scheme 3.

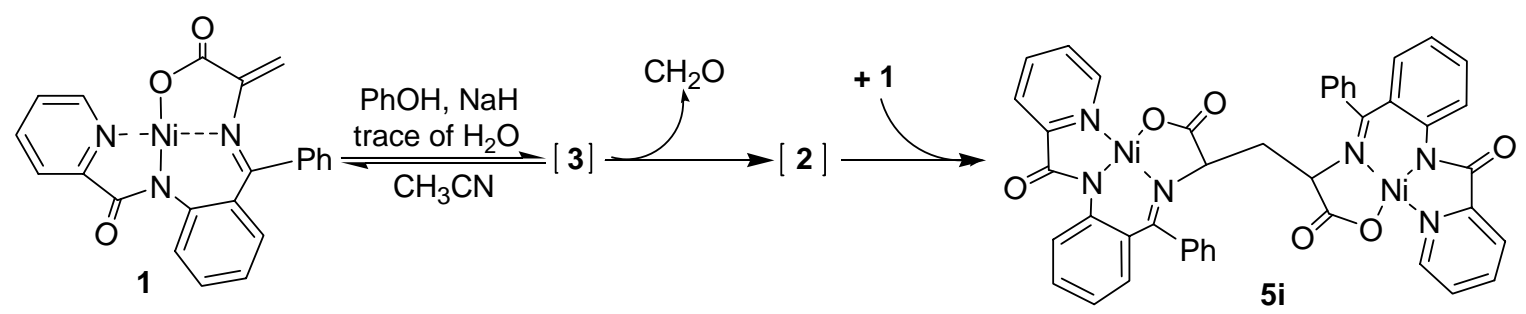

Scheme 3. A possible synthetic route leading to $\mathbf{5 i}$.

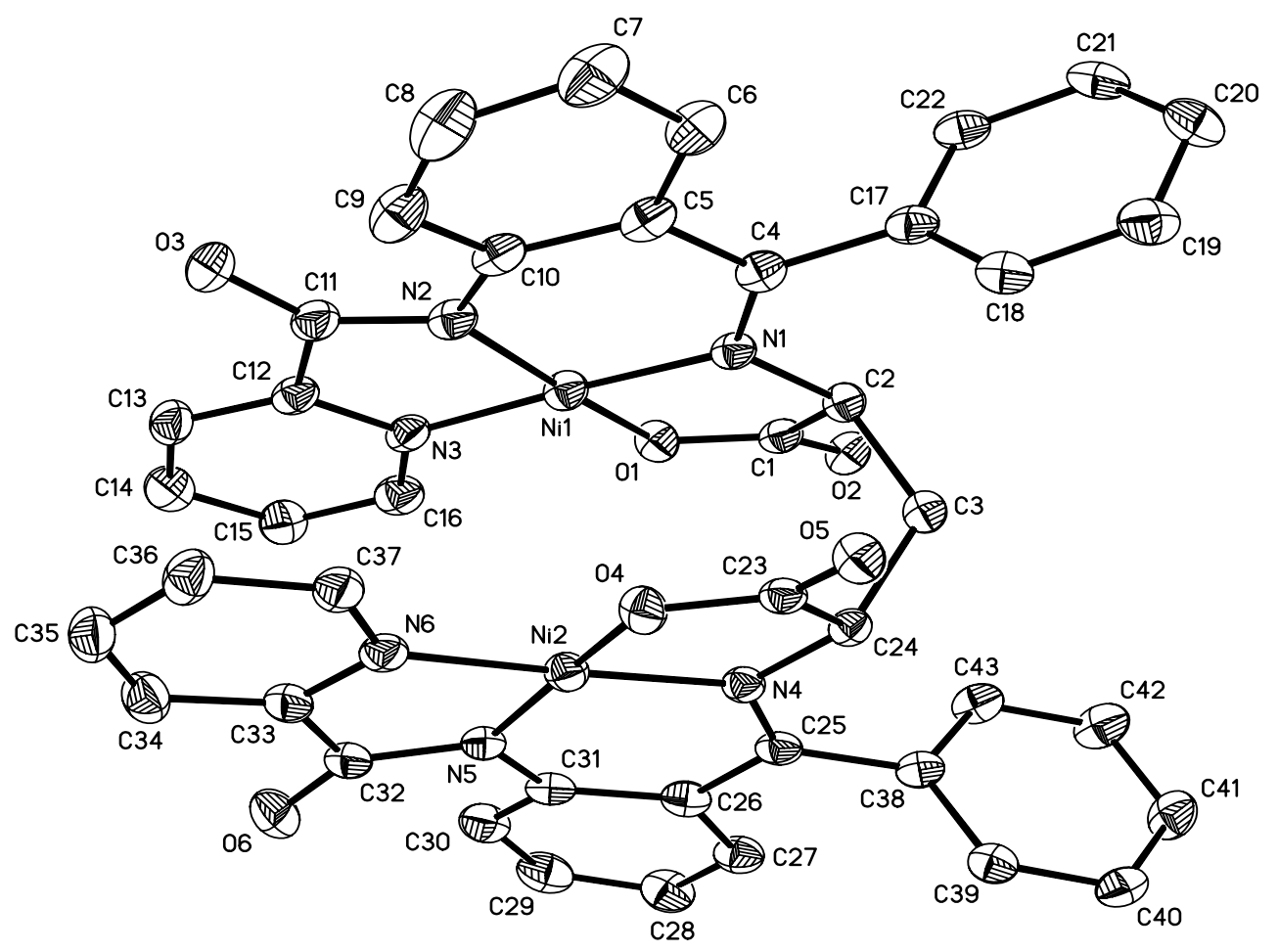

Figure 2. X-ray structure of complex $5 \mathbf{i}$. 
The addition of 2-naphtol to 1 was conducted in $\mathrm{MeCN}$ at a ratio 4/1 equal to 1.2 at $80^{\circ} \mathrm{C}$. The addition proceeded via C(1) of 2-naphtol, according to Scheme 4. It was proved by the presence of $\mathrm{OH}$ band in the IR spectrum of the adduct and its COESY NMR spectra. The ${ }^{1} \mathrm{H} \mathrm{N}$ MR spectrum of 5h displays two doublets of an $\mathrm{AB}$ system at 7.04 and $7.29 \mathrm{ppm}$ that we attribute to the $\mathrm{C}(3)$ - and $\mathrm{C}(4)-\mathrm{H}$ atoms of the naphtyl moiety. In addition, there was a broad resonance at $9.9 \mathrm{ppm}$ assigned to the proton of the hydroxy group of the naphtyl moiety. Comparison of the ${ }^{13} \mathrm{C}$ spectra of $\mathbf{5 i}, \mathbf{5 h}$ and free 2-naphtol and, in addition, ${ }^{1} \mathrm{H}-{ }^{13} \mathrm{C}$ COSY spectra of $\mathbf{5 h}$ show resonances at 113.76 and 117.44, corresponding to the $\mathrm{C}(3)$ and $\mathrm{C}(1)$ atoms of the naphtyl moiety with $\mathrm{C}(1)$ bearing no hydrogen. Finally, interactions in ${ }^{1} \mathrm{H}_{-}{ }^{13} \mathrm{C}$ HMBC spectra of $\mathbf{5 h}$ testified that the $\mathrm{CH}_{2}$ group of the amino acid moiety is bonded to $\mathrm{C}(1)$.

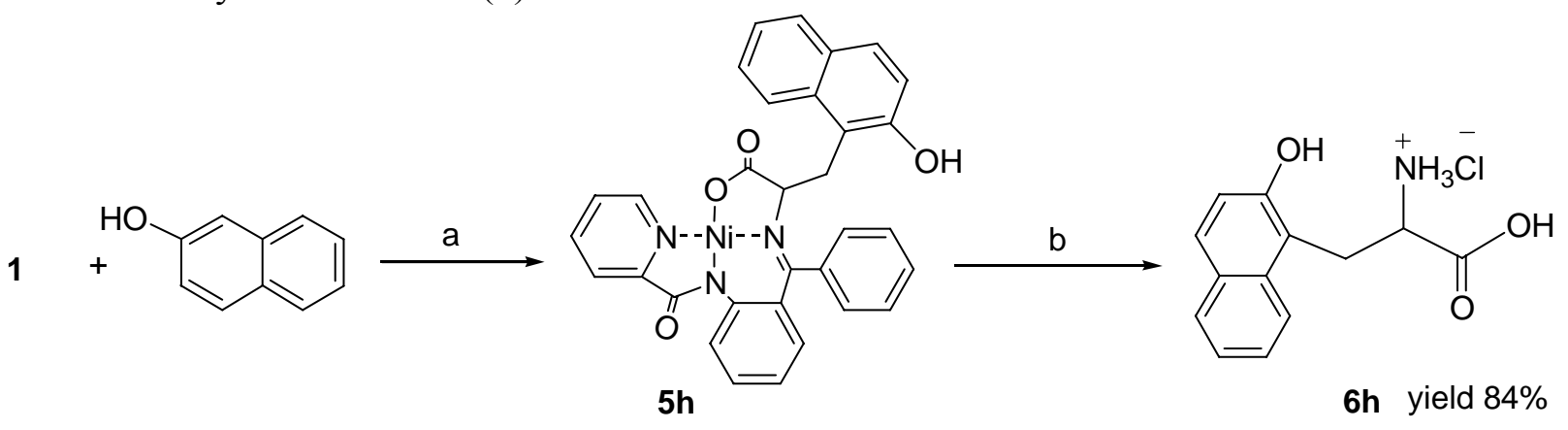

(a) $\mathrm{NaH}, \mathrm{CH}_{3} \mathrm{CN}, 80^{\circ} \mathrm{C}, 2 \mathrm{~h}$. (b) $6 \mathrm{~N} \mathrm{HCl} / \mathrm{MeOH}$.

Scheme 4. Addition of 2-naphthol to complex 1.

Thus, complex 1 constitutes a useful starting material that can be successfully employed for the synthesis of a variety of racemic $\alpha$-amino acids.

Next, we have attempted to use the substrate $\mathbf{1}$ in a catalytic asymmetric version of the Michael addition.

Recently we have shown that the asymmetric alkylation reaction of the complex $\mathbf{2}$ with alkyl halides could be performed catalytically with TADDOL or NOBIN (2'-Amino-[1,1']binaphthalenyl2-ol) as catalysts ${ }^{8,9}$ (Chart 1). We applied the same chiral catalysts in the addition of malonic ester to substrate 1 with the significant difference that the formation of a $\mathrm{C}-\mathrm{H}$ and not of a $\mathrm{C}-\mathrm{C}$ bond was the step introducing the chirality center.<smiles>CC1(C)OC(C(O)(c2ccccc2)c2ccccc2)C(C(O)(c2ccccc2)c2ccccc2)O1</smiles>

TADDOL<smiles>Nc1ccc2ccccc2c1-c1c(O)ccc2ccccc12</smiles>

NOBIN

\section{Chart 1}

NOBIN, although a good catalyst for the reaction, gave a disappointingly low enantiomeric excess of only $10 \%$, whereas TADDOL 7 a led to a sizable enantiopurity of the product (Table 2 ). 
The variation of bases and solvents lead to toluene and $t \mathrm{BuOK}$ or $\mathrm{KOH}$ as solvent and bases of choice (Table 2, run 9, 10).

A range of TADDOL derivatives were also tested as catalysts. Any substitution of $\mathrm{OH}$ groups in TADDOL 7a by $\mathrm{Cl}$-, $\mathrm{SH}-, \mathrm{NHCOCF}_{3}$ or $\mathrm{NH}_{2}$ - groups invariably decreased the enantioselectivity of the process (Table 3, run 1-6).

Table 2. Reaction of the dehydroalanine derivative $\mathbf{1}^{\mathrm{a}}$ with $\mathrm{CH}_{2}\left(\mathrm{CO}_{2} \mathrm{Et}\right)_{2}{ }^{\mathrm{b}}$, catalyzed by $10 \% \mathrm{~mol}$ of $(R, R)$-TADDOL $7 \mathbf{a}$

\begin{tabular}{ccccccc}
\hline Run & Solvent & $\begin{array}{c}\text { Base } \\
{[0.2 \mathrm{eq}]}\end{array}$ & $\begin{array}{c}\text { Temp } \\
{\left[{ }^{0} \mathrm{C}\right]}\end{array}$ & $\begin{array}{c}\text { Time } \\
{[\mathrm{min}]}\end{array}$ & $\begin{array}{c}\text { Yield of 5a } \\
{[\%]}\end{array}$ & $\begin{array}{c}\text { ee of }(S)-6 a \\
{[\%]^{\mathrm{d}}}\end{array}$ \\
\hline 1 & $\mathrm{CH}_{2} \mathrm{Cl}_{2}$ & $\mathrm{NaH}$ & 20 & 4 & 79 & 12 \\
2 & $\mathrm{CH}_{2} \mathrm{Cl}_{2}$ & $\mathrm{NaH}$ & 40 & 4 & 88 & 15 \\
3 & $\mathrm{CH}_{2} \mathrm{Cl}_{2}$ & $\mathrm{NaH}$ & -20 & 5 & 35 & 12 \\
4 & $\mathrm{CH}_{2} \mathrm{Cl}_{2}$ & $t \mathrm{BuLi}$ & 20 & 4 & 82 & 9 \\
5 & $\mathrm{CH}_{2} \mathrm{Cl}_{2}$ & $t \mathrm{BuOK}$ & 20 & 4 & 82 & 36 \\
6 & $\mathrm{Hexane}_{7}$ & $t \mathrm{BuOK}$ & 20 & 30 & 8 & 0 \\
7 & Toluene & $\mathrm{NaH}$ & 20 & 30 & 30 & 21 \\
9 & Toluene & $t \mathrm{BuOK}$ & 20 & 5 & 15 & 54 \\
10 & Toluene & $\mathrm{KOH}$ & 20 & 5 & 17 & 54 \\
11 & Toluene & $\mathrm{NaOH}$ & 20 & 5 & 20 & 29 \\
\hline
\end{tabular}

${ }^{\mathrm{a}}$ The substrate was $0.115 \mathrm{M} .{ }^{\mathrm{b}} 4$ Equivalents $\mathrm{CH}_{2}\left(\mathrm{CO}_{2} \mathrm{Et}\right)_{2} .{ }^{\mathrm{c}}$ The yield of product was calculated from 1 and determined by weighing the isolated complex 5a. ${ }^{\mathrm{d}}$ GLC Analysis of isolated amino acids were performed on chiral Chirasil-Val columns.

Changing the substitutes on TADDOL from ketal $\left(\mathrm{R}_{1}, \mathrm{R}_{2} \neq \mathrm{H}\right)$ to acetal $\left(\mathrm{R}_{2}=\mathrm{H}\right)$ also influenced the outcome of the reaction. For example, the TADDOLs $\mathbf{7 j - 0}$ gave very moderate enantioselectivities in the range of 18-37\% (Table 3, run 10-15). Changing the aryl group of the catalysts led to striking effect on the enantioselctivities: the original TADDOL 7a and the $\left(\mathrm{CF}_{3}\right)_{2}-$ substituted TADDOL $7 \mathbf{t}$ gave rise to ee values of 54\% and $<1 \%$ respectively (Table 3 , runs 1 and 19). Another type of electron-withdrawing aryl group, $\mathrm{C}_{6} \mathrm{~F}_{5}$, resulted in reversal of the product sense of chirality (Table 3 , runs 1 and 20).

The derivative 7e containing two TADDOL moieties did not lead to any significant change of stereoselectivity or yield (Table 3, run 5). Substitution of the 2-napthyl moieties for Ph resulted in some decrease of the stereoselectivity (Table 3, run 1 and 8). The TADDOL with 1-napthyl groups (7s and 7g) invariably led to increased enantioselectivities (Table 3, run 1 and 7, 17 and 18) and gave a maximum of $75 \%$ ee of $\mathbf{5 a}$ at ambient temperature, although in poor yield.

An attempt to increase the yields of the reaction by changing either the nature of the base or its amount at $20^{\circ} \mathrm{C}$ were unsuccessful (Table 4, runs 1-5) with partial racemization of 5a, accompanying the increase in the amount of the base (Table 4, runs 3 and 5). The yield of the reaction (up to $80 \%$ ) and its ee (up to $80 \%$ ) could be increased by switching to higher temperature 
of $70^{\circ} \mathrm{C}$ with $t \mathrm{BuOK}$ serving as a base (Table 4 , run 6). Increase of the size of the cation ( $\mathrm{Rb}$ and $\mathrm{Cs}$ instead of K) had little influence on yield and ee (Table 4, runs 7 and 8). The optimal ratio of base/catalyst/Ni-substrate at room temperature was $0.1 / 0.05 / 1$.

Table 3. Reaction of substrate 1 with $\mathrm{CH}_{2}\left(\mathrm{CO}_{2} \mathrm{Et}\right)_{2}$, catalyzed by 7a-u in toluene in the presence of 0.2 eq. $t \mathrm{BuOK}$

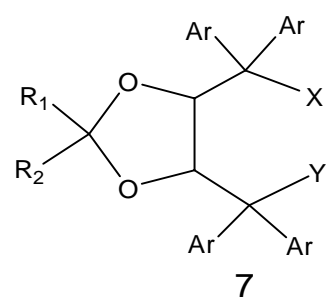

7

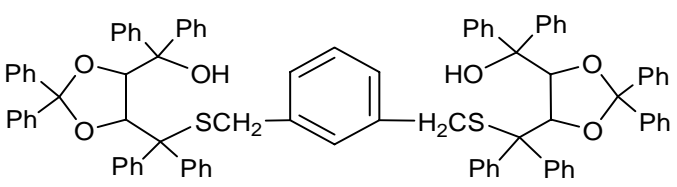

$7 e$

\begin{tabular}{|c|c|c|c|c|c|c|c|c|}
\hline $\begin{array}{c}\text { Run } \\
\text { a }\end{array}$ & 7 & $\mathrm{R}_{1}$ & $\mathrm{R}_{2}$ & $\mathrm{Ar}$ & $\mathrm{X}$ & $\mathrm{Y}$ & $\begin{array}{l}\text { Yield of } \\
\mathbf{5 a}[\%]^{b}\end{array}$ & $\begin{array}{c}\text { ee of }(S)-\mathbf{6 a} \\
{[\%]}\end{array}$ \\
\hline 1 & $\mathbf{A}$ & $\mathrm{Me}$ & $\mathrm{Me}$ & $\mathrm{Ph}$ & $\mathrm{OH}$ & $\mathrm{OH}$ & 18 & 54 \\
\hline 2 & B & $\mathrm{Me}$ & $\mathrm{Me}$ & $\mathrm{Ph}$ & $\mathrm{OH}$ & $\mathrm{SH}$ & 28 & 19 \\
\hline 3 & $\mathbf{C}$ & $\mathrm{Me}$ & $\mathrm{Me}$ & $\mathrm{Ph}$ & $\mathrm{OH}$ & $\mathrm{NH}_{2}$ & 25 & 13 \\
\hline 4 & D & $\mathrm{Me}$ & $\mathrm{Me}$ & $\mathrm{Ph}$ & $\mathrm{OH}$ & $\mathrm{NHCOCF}_{3}$ & 25 & 19 \\
\hline 5 & $\mathbf{E}$ & $\mathrm{Me}$ & $\mathrm{Me}$ & $\mathrm{Ph}$ & $\mathrm{OH}$ & see formula & 31 & 22 \\
\hline 6 & $\mathbf{f} * \mathrm{OEt}_{2}$ & $\mathrm{Me}$ & $\mathrm{Me}$ & $\mathrm{Ph}$ & $\mathrm{OH}$ & NH-SO $\mathrm{CF}_{3}$ & 11 & 15 \\
\hline 7 & $\mathbf{g} * \mathrm{MeOH}$ & $\mathrm{Me}$ & $\mathrm{Me}$ & Naphtyl-1 & $\mathrm{OH}$ & $\mathrm{OH}$ & 30 & 75 \\
\hline 8 & H & $\mathrm{Me}$ & $\mathrm{Me}$ & Naphtyl-2 & $\mathrm{OH}$ & $\mathrm{OH}$ & 32 & 35 \\
\hline 9 & I & $\mathrm{Ph}$ & $\mathrm{Ph}$ & $\mathrm{Ph}$ & $\mathrm{OH}$ & $\mathrm{OH}$ & 30 & 44 \\
\hline 10 & $\mathbf{J}$ & $\mathrm{Ph}$ & $\mathrm{H}$ & $\mathrm{Ph}$ & $\mathrm{OH}$ & $\mathrm{OH}$ & 34 & 34 \\
\hline $11^{\mathrm{c}}$ & $\mathbf{K}$ & $p$-BrPh & $\mathrm{H}$ & $\mathrm{Ph}$ & $\mathrm{OH}$ & $\mathrm{OH}$ & 28 & 18 \\
\hline $12^{\mathrm{c}}$ & $\mathbf{L}$ & $p-\mathrm{BrPh}$ & $\mathrm{H}$ & $\mathrm{Ph}$ & $\mathrm{OH}$ & OTMS & 28 & 9 \\
\hline $13^{\mathrm{c}}$ & $\mathbf{M}$ & $p-\mathrm{BrPh}$ & $\mathrm{H}$ & $\mathrm{Ph}$ & OTMS & OTMS & 16 & 18 \\
\hline 14 & $\mathbf{N}$ & Naphtyl-1 & $\mathrm{H}$ & $\mathrm{Ph}$ & $\mathrm{OH}$ & $\mathrm{OH}$ & 31 & 30 \\
\hline 15 & $\mathbf{O}$ & $t \mathrm{Bu}$ & $\mathrm{H}$ & $\mathrm{Ph}$ & $\mathrm{OH}$ & $\mathrm{OH}$ & 33 & 37 \\
\hline 16 & $\mathbf{P}$ & $\mathrm{tBu}$ & $\mathrm{H}$ & Naphtyl-1 & $\mathrm{OH}$ & $\mathrm{OH}$ & 30 & $56-62$ \\
\hline 17 & $\mathbf{R}$ & $-\left(\mathrm{CH}_{2}\right)_{5}-$ & & $\mathrm{Ph}$ & $\mathrm{OH}$ & $\mathrm{OH}$ & 30 & 50 \\
\hline 18 & $\mathbf{S}$ & $-\left(\mathrm{CH}_{2}\right)_{5}-$ & & Naphtyl-1 & $\mathrm{OH}$ & $\mathrm{OH}$ & 29 & 62 \\
\hline $19^{\mathrm{d}}$ & $\mathbf{T}$ & $\mathrm{Me}$ & $\mathrm{Me}$ & $3,5\left(\mathrm{CF}_{3}\right)_{2} \mathrm{Ph}$ & $\mathrm{OH}$ & $\mathrm{OH}$ & 90 & 0 \\
\hline $20^{\mathrm{e}}$ & $\mathbf{U}$ & $\mathrm{Me}$ & $\mathrm{Me}$ & $\mathrm{C}_{6} \mathrm{~F}_{5}$ & $\mathrm{OH}$ & $\mathrm{OH}$ & 54 & $(R)-41$ \\
\hline
\end{tabular}

${ }^{\text {a }}$ Reaction conditions: the reactions were run in toluene, concentration of $\mathbf{1}$ is $0.115 \mathrm{M}$, ratio of the $\mathrm{CH}_{2}\left(\mathrm{CO}_{2} \mathrm{Et}\right)_{2}:$ substrate $=4: 1,7$ :substrate $=1: 10, \mathrm{tBuOK}:(R, R)-7=2: 1$, room temperature, 15 minute, under Ar. ${ }^{\mathrm{b}}$ Yield of the product determined after separation from unreacted $1 .{ }^{\mathrm{c}}$ Compounds $7 \mathrm{k}, 1, \mathrm{~m}$ were prepared by O.Larionov in Zürich and will be described elsewhere. ${ }^{\mathrm{d}}$ The reaction was run at $70{ }^{0} \mathrm{C}$ for $4 \mathrm{~min}$. ${ }^{\mathrm{e}}$ The reaction was run at $70{ }^{0} \mathrm{C}$ for $15 \mathrm{~min}$ with ratio of $\mathrm{CH}_{2}\left(\mathrm{CO}_{2} \mathrm{Et}\right)_{2}$ :substrate:7:tBuOK $=$ 4:1:0.05:1.2. 
Table 4. Reaction of complex 1 with $\mathrm{CH}_{2}\left(\mathrm{CO}_{2} \mathrm{Et}\right)_{2}$, catalyzed by $\mathbf{7 g}$ in toluene

\begin{tabular}{ccccccc}
\hline Run $^{\mathrm{a}}$ & $\begin{array}{c}\text { Catalyst } \\
\mathbf{7 g}[\mathrm{eq}]\end{array}$ & Base [eq] & $\begin{array}{c}\text { Temp } \\
{\left[{ }^{0} \mathrm{C}\right]}\end{array}$ & $\begin{array}{c}\text { Time } \\
{[\mathrm{min}]}\end{array}$ & $\begin{array}{c}\text { Yield of 5a } \\
{[\%]}\end{array}$ & $\begin{array}{c}\text { ee of } \mathbf{6 a} \\
{[\%]}\end{array}$ \\
\hline 1 & 0.1 & $\mathrm{NaOH}(0.2)$ & 20 & 15 & 31 & 32 \\
2 & 0.1 & $\mathrm{KOH}(0.2)$ & 20 & 15 & 31 & 67 \\
3 & 0.1 & $t \operatorname{BuOK}(0.2)$ & 20 & 15 & 30 & 75 \\
4 & 0.1 & $t \mathrm{BuOK}(0.1)$ & 20 & 15 & 18 & 65 \\
5 & 0.4 & $t \mathrm{BuOK}(0.8)$ & 20 & 15 & 44 & 55 \\
6 & 0.05 & $t \mathrm{BuOK}(0.1)$ & 70 & 4 & 80 & 80 \\
7 & 0.05 & $50 \% \mathrm{RbOH}(0.1)$ & 70 & 4 & 76 & 52 \\
8 & 0.05 & $\mathrm{CsOH} \cdot \mathrm{H} 2 \mathrm{O}(0.1)$ & 70 & 4 & 70 & 77 \\
9 & 0.05 & $t \mathrm{BuOK}(0.1)$ & 70 & 20 & 91 & 55 \\
10 & 0.05 & $t \mathrm{BuOK}(0.1)$ & 20 & 360 & 48 & 76 \\
\hline
\end{tabular}

${ }^{a}$ Reaction conditions: the concentration is $0.115 \mathrm{M}$, ratio of the $\mathrm{CH}_{2}\left(\mathrm{CO}_{2} \mathrm{Et}\right)_{2}: \mathbf{1}=4: 1$. ${ }^{\mathrm{b}}$ Yield of the product 5a determined after separation from unreacted $\mathbf{1}$.

Some racemization of $\mathbf{5 a}$ was observed if the reaction was run longer than 4 minutes (Table 4, run 9 ). The enantiomeric purity of $\mathbf{5 a}$ could be improved up to ee $88 \%$ by a single recrystallyzation (Table 4, run 6)

Experiments with other nucleophiles in asymmetric version of the reaction showed that the most efficient nucleophiles were other derivatives of malonic ester, which gave moderate enantioselectivities and yields (Table 5, runs 1-3), whereas thiophenol added to 1 totally nonselectively (Table 5, run 4). Also amines as nucleophiles reacted with 1 without any detectable enantioselectivity.

Table 5. Reaction of the complex 1 with different type of nucleophils catalyzed by $(R)-7 \mathrm{~g}$ in toluene at $70^{\circ} \mathrm{C}$

\begin{tabular}{ccccccc}
\hline Run $^{\mathrm{a}}$ & \multirow{2}{*}{$\mathrm{NuH}$} & $(S)-\mathbf{5}$ & $\begin{array}{c}\text { tBuOK } \\
{[\mathrm{eq}]}\end{array}$ & $\begin{array}{c}\text { Time } \\
{[\mathrm{min}]}\end{array}$ & $\begin{array}{c}\text { Yield of 5 } \\
{[\%]^{\mathrm{b}}}\end{array}$ & $\begin{array}{c}\text { ee of }(S)-5 \\
{[\%]}\end{array}$ \\
\hline 1 & $\mathrm{CH}_{2}(\mathrm{COOEt})_{2}$ & $\mathbf{a}$ & 0.1 & 4 & 80 & $80^{\mathrm{c}}(88 \%)^{\mathrm{d}}$ \\
2 & $\mathrm{AcNHCH}(\mathrm{COOEt})_{2}$ & $\mathbf{b}$ & 0.1 & 4 & 65 & $78^{\mathrm{e}}(80)^{\mathrm{d}}$ \\
3 & BocNHCH$(\mathrm{COOEt})_{2}$ & $\mathbf{c}$ & 0.1 & 4 & 56 & $64^{\mathrm{e}}(83)^{\mathrm{d}}$ \\
4 & $\mathrm{PhSH}$ & d & 0.1 & 4 & 64 & $<1$ \\
\hline
\end{tabular}

a Reaction conditions: the reactions were run in toluene, concentration of $10.115 \mathrm{M}$, ratio of the 1:NuH:7g:tBuOK=1:4:0.05:0.1, $70^{\circ} \mathrm{C}$, under Ar. ${ }^{b}$ Yield of the product 5 determined after separation from unreacted 1. ${ }^{\mathrm{c}}$ Enantiomeric excess was determined by GLC analysis on chiral column. ${ }^{\mathrm{d}}$ The ee was determined after crystallization. ${ }^{\mathrm{e}}$ The ee was determined by comparison of optical rotations. 


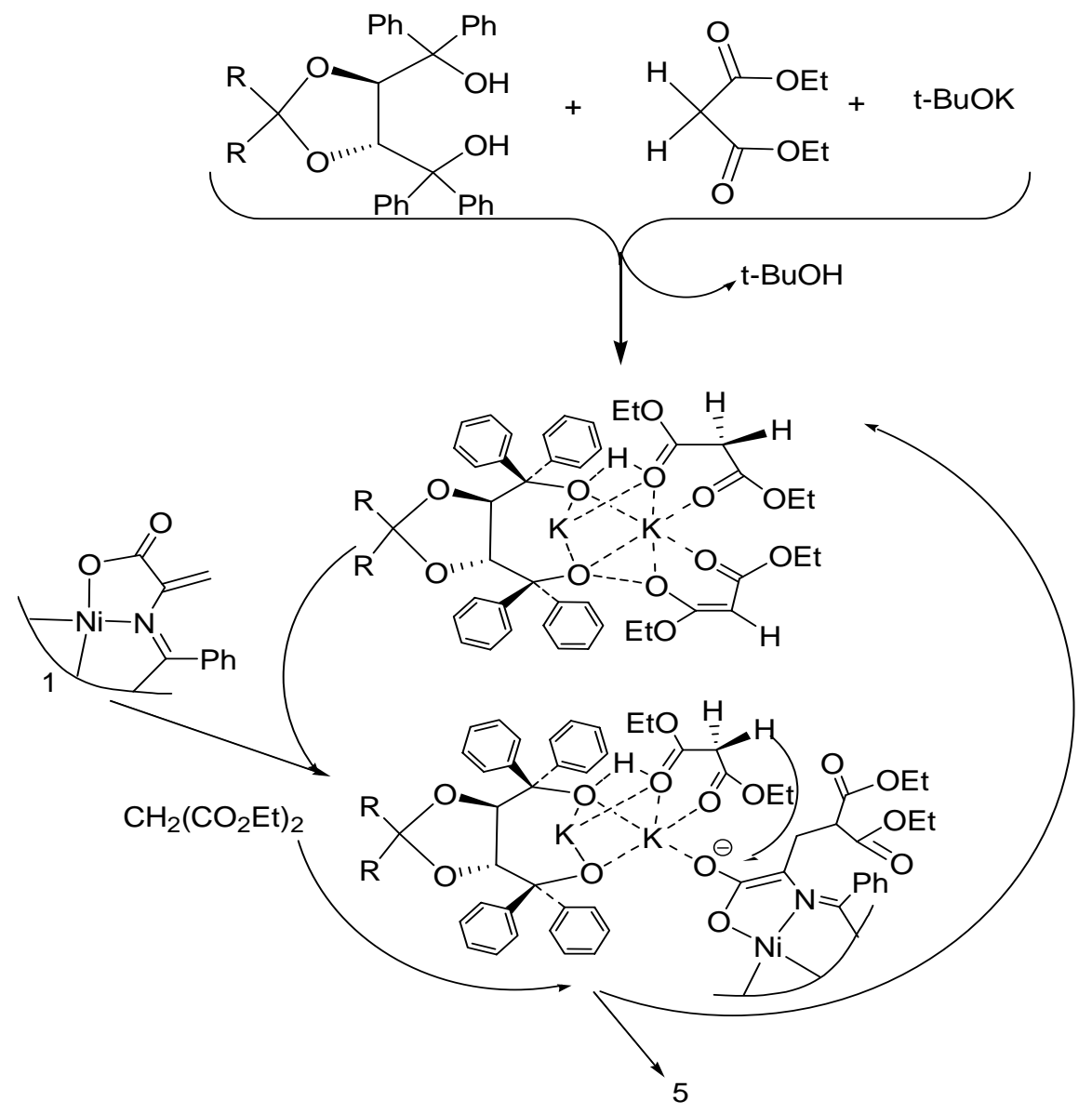

Scheme 5. A hypothetical mechanism for the overall Michael addition of malonic ester to 1 catalyzed by TADDOL.

As the enantioselectivity of the reaction is determined in the protonation step of the intermediate enolate, the observed results are not likely to be due to protonation by TADDOL: the pKa of TADDOLs in DMSO would most likely lie in the range 28-30 whereas 2 and derivatives such as 5 have a $\mathrm{pKa}$ in the range of 17-19. ${ }^{11}$ On the other hand, malonic esters and acetylacetate do have their $\mathrm{pKa}$ close to that of $\mathbf{5}$ and, in addition, are capable of chelating alkali ions. An admittedly speculative mechanism of the process (Scheme 5) might include the formation of a mixed chelate of TADDOL and malonic ester, with the latter functioning to deliver a proton to quench the intermediate enolate of $\mathbf{5}$. The function of TADDOL might be the increase of malonic ester acidity by hydrogen bonding and forming a chiral environment for recognition of the enantiotopic enolate of 5 in the cause of proton transfer. 


\section{Conclusions}

A new type of substrate based on an achiral Ni(II) complex of a Schiff base of dehydroalanine was elaborated for the synthesis of amino acids. We have developed an efficient catalytic method of asymmetric 1,4 conjugate addition of $\mathrm{CH}$-acids to Michael acceptors catalyzed by TADDOLs.

\section{Experimental Section}

General Procedures. ${ }^{1} \mathrm{H}$ and ${ }^{13} \mathrm{C}$ NMR spectra were recorded on a Bruker AMX 400 and Avance300 spectrometers with $400.13 \mathrm{MHz}$ and $300.13 \mathrm{MHz}$ accordingly. The resonances in ${ }^{1} \mathrm{H}$ and ${ }^{13} \mathrm{C}$ spectra of $\mathbf{5 f}, \mathbf{5 h}$, and $\mathbf{5 i}$ were attributed to the corresponding ${ }^{1} \mathrm{H}$ and ${ }^{13} \mathrm{C}$ nucleus according to a series of 1D and 2D homo- and heteronuclear experiments such as ${ }^{1} \mathrm{H}-{ }^{1} \mathrm{H}$ COSY,${ }^{1} \mathrm{H}^{13}{ }^{13} \mathrm{C}$ COSY and also ${ }^{1} \mathrm{H}-{ }^{13} \mathrm{C}$ HMBC experiments with $J$-filtration to suppress 1,3 spin-spin interactions. Very significant overlap of resonances in ${ }^{1} \mathrm{H}$ spectra made difficult to attribution of the resonances to the protons of pyridine and phenyl moieties.

The numbering of atoms in the PBP moiety of every Ni-complex in experiment section corresponds to the numeration in X-ray structure of 5a (Fig.1).

IR spectra were made on a "Magna-IR 750" spectrometer (Nicolet). The optical rotations angles were measured on a Perkin-Elmer 241 polarimeter. Chiral GLC analyses of the amino acids were performed on a Chirasil-L-Val type phase, by using n-propyl esters of N-trifluoroacetyl derivatives of amino acids. All manipulations were performed under dried and deoxygenated argon. Reactions were carried out in a flame-dried round-bottomed flasks equipped with a magnetic stir bar and water- cooled reflux condenser. All the reagents were acquired from Aldrich. TADDOLs were available from previous work. ${ }^{12}$

Crystal structure determination. Data were collected on a Bruker SMART 1000 CCD diffractometer $(\lambda(\mathrm{MoK} \alpha)$-radiation, graphite monochromator, $\varphi$ and $\theta$ scan mode) and corrected for Lorentz and polarization effects and for absorption ${ }^{13}$; details are given in Table 6. The structures were determined by direct methods and by full-matrix least squares refinement with anisotropic thermal parameters for non-hydrogen atoms. The crystal of $\mathbf{5 i}$ contains seven solvate chloroform molecules one of which is disordered over two sites with occupancies 0.6 and 0.4 , respectively. The hydrogen atoms of both compounds were placed in calculated positions and refined in riding model with fixed thermal parameters $\left(\mathrm{Uiso}(\mathrm{H})=1.5 \mathrm{Ueq}(\mathrm{C})\right.$ for the $\mathrm{CH}_{3}$-groups and $\operatorname{Uiso}(\mathrm{H})=1.2 \mathrm{Ueq}(\mathrm{C})$ for the other groups). All calculations were carried out by use of the SHELXTL (PC Version 5.10) program package. ${ }^{14}$

1.1. Pyridine-2-carboxylic acid(2-benzoyl-phenyl)-amide (PBP) and Ni(II) complex 2 derived from the Schiff base of PBP and 2-aminoacetic acid were synthesized by a procedure described previously. ${ }^{9}$ 
1.2. Synthesis of $\mathrm{Ni}(\mathrm{II})$ complex 3 derived from the Schiff base of PBP and $( \pm)$-serine. To the suspension of $2(10 \mathrm{~g}, 0.024 \mathrm{~mol})$ in $\mathrm{CH}_{3} \mathrm{OH}(90 \mathrm{ml})$ under $\mathrm{Ar}$ were added $\mathrm{CH}_{3} \mathrm{ONa}(22 \mathrm{ml}, 4 \mathrm{~N})$ and $\left(\mathrm{CH}_{2} \mathrm{O}\right) \mathrm{n}(2 \mathrm{~g}, 0.067 \mathrm{~mol})$. The mixture was stirred under reflux for $1 \mathrm{~h}$ until disappearance of the initial complex. The course of the reaction was monitored by TLC $\left(\mathrm{CHCl}_{3}: \mathrm{CH}_{3} \mathrm{COCH}_{3}=5: 1\right)$. Then the reaction mixture was cooled down to r.t. and quenched with aq AcOH. The precipitate was filtered by dense filter, washed with water several times and dried at air to afford $\mathbf{3}$. The dry product $(10.1 \mathrm{~g}, 0.023 \mathrm{~mol}, 94 \%)$ was put in $60 \mathrm{ml}$ of $\mathrm{CHCl}_{3}$. The mixture was stirred at $\mathrm{rt}$ for $1 \mathrm{~h}$. The precipitate was filtered and dried at air to afford $9.45 \mathrm{~g}(0.021 \mathrm{~mol}, 88 \%)$ pure $\mathbf{3}$ with very low solubility in any organic solvents: $\mathrm{mp} 249-253{ }^{\circ} \mathrm{C}$. Anal. Calcd for $\mathrm{C}_{22} \mathrm{H}_{17} \mathrm{~N}_{3} \mathrm{NiO}_{4}$ : C, 59.23; $\mathrm{H}$, 3.84; N, 9.42; Found: C, 59.21; H, 3.78; N, 9.36; ${ }^{1} \mathrm{H}$ NMR (400.13 MHz, $\left.\mathrm{CDCl}_{3}\right): \delta: 2.83(\mathrm{~m}, 1 \mathrm{H}$, $\mathrm{OH}) ; 3.78\left(\mathrm{~m}, 1 \mathrm{H}, \mathrm{CH}_{2}\right) ; 3.96\left(\mathrm{~m}, 1 \mathrm{H}, \mathrm{CH}_{2}\right) ; 4.10(\mathrm{~m}, 1 \mathrm{H}, \mathrm{CH}) ; 6.8(\mathrm{~m}, 2 \mathrm{H}, \mathrm{ArH}) ; 7.12(\mathrm{~d}, 1 \mathrm{H}$, $\operatorname{ArH}(\mathrm{CH}-17), J=7.4 \mathrm{~Hz}) ; 7.29$ (m, 1H, ArH); 7.37 (m, 1H, ArH); 7.45 (m, 1H, ArH); 7.55 (m, 3H, $\operatorname{ArH}) ; 7.92$ (d, 1H, ArH, $J=7.8 \mathrm{~Hz}) ; 8.02$ (м, 1H, ArH); 8.22 (d, 1H, $\operatorname{ArH}(\mathrm{CH}-29), J=4.0 \mathrm{~Hz})$; 8.95 (d, 1H, ArH(CH-14), J=8.8 Hz); IR, ( $/ \mathrm{cm}^{-1}$; KBr): 1654 (COO), 1638 (amide); $1606(\mathrm{C}=\mathrm{N})$, 1586 (amide); $3270(\mathrm{OH})$.

\subsection{Synthesis of Ni(II) complex 1 derived from the Schiff base of PBP and 2-amino-acrylic} acid. The mixture of $3(9 \mathrm{~g}, 0.02 \mathrm{~mol})$ in $68 \mathrm{ml} \mathrm{CH} \mathrm{CH}_{3} \mathrm{CN}$ and $\mathrm{Ac}_{2} \mathrm{O}(15 \mathrm{ml})$ was stirred for $1 \mathrm{~h}$ under reflux. $\mathrm{Na}_{2} \mathrm{CO}_{3}(6.36 \mathrm{~g}, 0.06 \mathrm{~mol})$ was then added. The reaction mixture was stirred under Ar at reflux for 5-6 $\mathrm{h}$ until disappearance of the initial complex. The course of the reaction was monitored by TLC $\left(\mathrm{CHCl}_{3}: \mathrm{CH}_{3} \mathrm{COCH}_{3}=5: 1\right)$. The reaction mixture was quenched by adding $500 \mathrm{ml}$ water. After $1 \mathrm{~h}$ the precipitate was filtered, washed with water and dried over $\mathrm{P}_{2} \mathrm{O}_{5}$ giving 1 (8.2 g, $0.019 \mathrm{~mol}, 96 \%$ ). The isolated product was then refluxed in $80 \mathrm{ml} \mathrm{MeOH}$ during $1 \mathrm{~h}$. Then the mixture was cooled down to r.t. and precipitate was filtered and dried at air to afford pure product 1 (7.6g, 0.018mol, 89\%): mp 259-262 ${ }^{\circ} \mathrm{C}$. Anal. Calcd for $\mathrm{C}_{22} \mathrm{H}_{15} \mathrm{~N}_{3} \mathrm{NiO}_{3}$ : C, 61.73; H, 3.53; N, 9.82; Found C, 61.77; H, 3.44; N, 9.91; ${ }^{1} \mathrm{H}$ NMR (400.13 MHz, $\left.\mathrm{CDCl}_{3}\right): \delta: .4 .22\left(\mathrm{~d}, 1 \mathrm{H},=\mathrm{CH}_{2}, J=1.3\right.$ $\mathrm{Hz}) 5.68\left(\mathrm{~d}, 1 \mathrm{H},=\mathrm{CH}_{2}, J=1.3 \mathrm{~Hz}\right) ; 6.82(\mathrm{t}, 1 \mathrm{H}, \operatorname{ArH}(\mathrm{CH}-16), J=7.6 \mathrm{~Hz}) ; 7.02(\mathrm{dd}, 1 \mathrm{H}, \operatorname{ArH}(\mathrm{CH}-$ 17), $J=8.4 \mathrm{~Hz}, J=1.6 \mathrm{~Hz}) ; 7.20$ (m, 2H, ArH); 7.38 (m, 1H, ArH); 7.45-7.55 (m, 4H, ArH); 7.92 (m, 1H, ArH); 8.02 (t, 1H, J = 7.8 Hz, ArH); 8.25 (d, 1H, $\operatorname{ArH}(\mathrm{CH}-29), J=5.0 \mathrm{~Hz}) ; 8.9$ (d, $1 \mathrm{H}$, $\operatorname{ArH}(\mathrm{CH}-14), J=8.7 \mathrm{~Hz}) ;{ }^{13} \mathrm{C}$ NMR $\left(400.13 \mathrm{MHz}, \mathrm{CDCl}_{3}\right): \delta 116.34\left(=\mathrm{CH}_{2}\right) ; 121.47(\mathrm{C}-16) ; 123.27$ (C-17); 124.18 (C-14); 127.03 (C-15); 127.42 (C-11); 128.18; 129.26; 130.22; 134.30; 135.52; 135.64 (C-18); $140.61 ; 144.17$ (C-13); 146.89 (C-29); 147.16 (=C); 153.15 (C-25); 169.68; 170.63. IR ( $\left./ \mathrm{cm}^{-1} ; \mathrm{KBr}\right): 1667(\mathrm{COO}), 1646($ amide); $1606(\mathrm{C}=\mathrm{N}), 1586$ (amide).

\subsection{Typical procedure for the asymmetric Michael addition as illustrated by synthesis of 5 a}

\subsubsection{Ni(II) Complex 5a of a Schiff base of PBP and (S)-2-amino-4-ethoxycarbonyl-} pentanedioic acid 5-ethyl ester. $(R)-7 \mathrm{~g}(0.082 \mathrm{~g}, 0.117 \mathrm{mmol})$ was dissolved in toluene $(20 \mathrm{ml})$ and the solution was carefully purged with $\mathrm{Ar}$, then $(0.026 \mathrm{~g}, 0.23 \mathrm{mmol}) \mathrm{C}_{4} \mathrm{H}_{9} \mathrm{OK}$ were added into the solution with stirring under Ar at room temperature. After $9 \mathrm{~min}$, the initial 1 (1g, 2.3mmol) was added to the mixture under Ar with stirring at $70^{\circ} \mathrm{C}$, followed 6 min later by malonic ethyl ester 
$(1.49 \mathrm{~g}, 9.3 \mathrm{mmol})$ and the reaction mixture was agitated for additional $4 \mathrm{~min}$ at $70^{\circ} \mathrm{C}$ [the course of the reaction was monitored by TLC $\left.\left(\mathrm{CHCl}_{3} / \mathrm{Me}_{2} \mathrm{CO}, 5 / 1\right)\right]$. Then the reaction mixture was quenched with aq $\mathrm{AcOH}$ and some $\mathrm{CH}_{2} \mathrm{Cl}_{2}$ was added to the solution. The organic layer was separated and an aliquot was used to check ee of the glutamic acid (80\%). The remainder of the organic layer was evaporated and the residue $(1.17 \mathrm{~g}, 2 \mathrm{mmol}, 87 \%)$ purified by chromatography on $\mathrm{SiO}_{2}$ column $\left(\mathrm{CHCl}_{3} / \mathrm{Me}_{2} \mathrm{CO}, 5 / 1\right)$. The main fraction was evaporated giving the final Michael adduct with $(S)$ configuration and yield $80 \%(1 \mathrm{~g}, 1.84 \mathrm{mmol}):[\alpha]^{25}{ }_{\mathrm{D}}+2127^{\circ}\left(\mathrm{c} 0.02, \mathrm{CHCl}_{3}\right.$, for complex with ee $80 \%$.). After crystallization from mixture of $\mathrm{MeOH} / \mathrm{H}_{2} \mathrm{O}$ enantiomeric purity was increased up to $88 \%\left([\alpha]^{25}{ }_{D}+2340\right)$; mp $178-182^{\circ} \mathrm{C}$. Anal. Calcd. for $\mathrm{C}_{29} \mathrm{H}_{27} \mathrm{~N}_{3} \mathrm{NiO}_{7}$ : C, 59.21; $\mathrm{H}, 4.63 ; \mathrm{N}, 7.14$; Found (after cryst. ) C, 59.29; H, 4.68; N, 7.11; ${ }^{1} \mathrm{H}$ NMR $\left(400.13 \mathrm{MHz}, \mathrm{CDCl}_{3}\right): \delta 1.15$ (t, 3H, Me, $J=7.1 \mathrm{~Hz}) ; 1.18(\mathrm{t}, 3 \mathrm{H}, \mathrm{Me}, J=7.1 \mathrm{~Hz}) ; 2.21,2.67\left(\mathrm{~m}, 2 \mathrm{H}, \mathrm{CH}_{2}\right) ; 3.96-4.19\left(\mathrm{~m}, 5 \mathrm{H}, \mathrm{CH}, 2 \mathrm{CH}_{2}\right)$; $4.27(\mathrm{~m}, 1 \mathrm{H}, \mathrm{CH}) ; 6.77(\mathrm{~m}, 2 \mathrm{H}, \mathrm{ArH}) ; 7.23(\mathrm{~d}, 1 \mathrm{H}, \mathrm{ArH}, J=5.0 \mathrm{~Hz}) ; 7.35$ (m, 2H, ArH); $7.46(\mathrm{~m}$, $1 \mathrm{H}, \mathrm{ArH}) ; 7.54(\mathrm{~m}, 3 \mathrm{H}, \mathrm{ArH}) ; 7.91(\mathrm{~d}, 1 \mathrm{H}, \mathrm{ArH}, J=7.8 \mathrm{~Hz}) ; 8.01$ (t, 1H, ArH, J=7.8 Hz); 8.24 (d, $1 \mathrm{H}, \operatorname{ArH}(\mathrm{CH}-29), J=4.6 \mathrm{~Hz}) ; 8.97(\mathrm{~d}, 1 \mathrm{H}, \operatorname{ArH}(\mathrm{CH}-14), J=8.0 \mathrm{~Hz}) ;{ }^{13} \mathrm{C} \mathrm{NMR}(400.13 \mathrm{MHz}$, $\left.\mathrm{CDCl}_{3}\right): \delta 13.77\left(\mathrm{CH}_{3}\right) ; 13.83\left(\mathrm{CH}_{3}\right) ; 32.07\left(\mathrm{CH}_{2}\right) ; 48.18(\mathrm{CH}) ; 61.62\left(\mathrm{CH}_{2} \mathrm{CH}_{3}\right) ; 62.02\left(\mathrm{CH}_{2} \mathrm{CH}_{3}\right)$; $69.39\left(\mathrm{CHCH}_{2}\right) ; 121.35$ (C-16); 123.25 (C-17); 123.80 (C-14); 126.44 (C-11); 126.66; 126.92 (C15); 128.17; 128.91; 129.74; 133.56; 134.76; $140.50 ; 142.98$ (C-13); 146.82 (C-29); 153.03 (C-25); $168.19 ; 169.37 ; 169.90 ; 173.62 ; 178.24 ; \mathrm{IR},\left(\mathrm{v} / \mathrm{cm}^{-1}\right.$; KBr): 1678; 1648; 1606; 1590; 1746; 1728.

1.4.2. Synthesis of Ni(II) complex $5 \mathrm{~b}$ of a Schiff base of PBP and (S)-2-acetylamino-4-amino-2ethoxycarbonyl-pentanedioic acid 1-ethyl ester. The experiment was conducted similar to the one described in section 1.4.1. starting from $1(0.5 \mathrm{~g}, 1.17 \mathrm{mmol})$ in toluene $(10 \mathrm{ml})$, using $\mathrm{C}_{4} \mathrm{H}_{9} \mathrm{OK}$ $(0.0131 \mathrm{~g} 0.117 \mathrm{mmol})$ as a base, $7 \mathbf{g}(0.04 \mathrm{~g}, 0.0584 \mathrm{mmol})$ and 2-acetylamino-malonic acid diethyl ester $(0.75 \mathrm{~g}, 3.45 \mathrm{mmol})$. The reaction was over within $4 \mathrm{~min}$. Yield of $\mathbf{5 b}$ was $93 \%(0.7 \mathrm{~g}$, 1.1mmol): $[\alpha]^{25}{ }_{\mathrm{D}}+2090^{\circ}$ (c $0.02, \mathrm{CHCl}_{3}$, for complex with ee $78 \%$ assuming similar specific rotations of $\mathbf{5 a}$ and $\mathbf{5 b}$.). The product was crystallized from $\mathrm{CHCl}_{3} / \mathrm{Hexane}$ : $\mathrm{mp} 260^{0} \mathrm{C}$ (decomp). Anal. Calcd. for $\mathrm{C}_{31} \mathrm{H}_{30} \mathrm{~N}_{4} \mathrm{NiO}_{8} 0.5 \mathrm{CHCl}_{3}$ : C, 53.67; H, 4.36; N, 7.95; Found: C, 53.27; H, 4.19; N, 7.64; ${ }^{1} \mathrm{H}$ NMR (400.13 MHz, $\left.\mathrm{CDCl}_{3}\right): \delta 1.17(\mathrm{t}, 6 \mathrm{H}, \mathrm{Me}, J=7.0 \mathrm{~Hz}) ; 1.75(\mathrm{~s}, 3 \mathrm{H}, \mathrm{Ac}) ; 2.78,3.54$ (AB part of $\mathrm{ABX}$ system, $2 \mathrm{H}, \mathrm{CH}_{2}, J_{\mathrm{AB}}=14.56 \mathrm{~Hz}$ ); 3.97 (X part ABX of system, $1 \mathrm{H}, \mathrm{CH}, J_{\mathrm{AX}}=$ $\left.4.2 \mathrm{~Hz}, J_{\mathrm{BX}}=9.6 \mathrm{~Hz}\right) ; 4.0-4.24\left(\mathrm{~m}, 4 \mathrm{H}, 2 \mathrm{CH}_{2}\right) ; 6.72-6.79(\mathrm{~m}, 2 \mathrm{H}, \mathrm{ArH}) ; 7.14(\mathrm{bs}, 1 \mathrm{H}, \mathrm{ArH}) ; 7.2(\mathrm{~d}$, $1 \mathrm{H}, \operatorname{ArH}, J=4.0 \mathrm{~Hz}) ; 7.34$ (m, 1H, ArH); 7.44-7.59 (m, 4H, ArH); 7.95 (d, 1H, ArH, J=7.0 Hz); 8.03 (m, 1H, ArH); 8.16 (d, 1H, $\operatorname{ArH}(\mathrm{CH}-29), J=5.3 \mathrm{~Hz}) ; 8.96$ (d, 1H, $\operatorname{ArH}(\mathrm{CH}-14), J=9.0 \mathrm{~Hz})$; ${ }^{13} \mathrm{C} \mathrm{NMR}\left(400.13 \mathrm{MHz}, \mathrm{CDCl}_{3}\right): \delta 14.46\left(2 \mathrm{CH}_{3}\right) ; 23.33(\mathrm{Ac}) ; 37.05\left(\mathrm{CH}_{2}\right) ; 63.33\left(\mathrm{CH}_{2} \mathrm{CH}_{3}\right) ; 63.59$ $\left(\mathrm{CH}_{2} \mathrm{CH}_{3}\right) ; 64.90(\mathrm{C}) ; 68.65\left(\mathrm{CHCH}_{2}\right) ; 122.15(\mathrm{C}-16) ; 124.09(\mathrm{C}-17) ; 124.92(\mathrm{C}-14) ; 127.13(\mathrm{C}-$ $11) ; 127.34 ; 127.53$ (C-15); 129.31; 128.39; 130.22; 130.32; 133.92 (C-18); 134.36; 135.38; $141.29 ; 143.76$ (C-13); 147.10 (C-29); 154.12 (C-25); 167.59; 169.76; 170.53; 173.45; 179.11; $\delta$; (IR, (v/cm-1; KBr): 1667; 1640; 1605; 1591; 1684; 1744; 3414 (NH).

1.4.3. Synthesis of Ni(II) complex $5 \mathrm{c}$ of a Schiff base of PBP and (S) 4-amino-2-tertbutoxycarbonylamino-2-ethoxycarbonyl-pentanedioic acid 1-ethyl ester. The experiment was conducted similar to the one described in section 1.4.1., starting from $1(0.5 \mathrm{~g}, 1.17 \mathrm{mmol})$ in toluene (10ml), using $\mathrm{C}_{4} \mathrm{H}_{9} \mathrm{OK}(0.0131 \mathrm{~g} 0.117 \mathrm{mmol})$ as a base, $7 \mathrm{~g}(0.04 \mathrm{~g}, 0.0584 \mathrm{mmol})$ and 2-Boc-aminomalonic acid diethyl ester $(0.96 \mathrm{~g}, 3.5 \mathrm{mmol})$. The reaction was over within $4 \mathrm{~min}$. Yield of 5c was 
91\% (0.74g, 1.06mmol): $[\alpha]^{25}+1700^{\circ}$ (c $0.02, \mathrm{CHCl}_{3}$, for complex with ee $64 \%$.). The product was crystallized from $\mathrm{CHCl}_{3} /$ Hexane. Enantiomeric purity for precipitate was $<1 \%$ (35\% yield) and of the filtrate $80 \%$ (56\% yield): $\mathrm{mp} 238-240{ }^{\circ} \mathrm{C}$. Anal. Calcd. for $\mathrm{C}_{34} \mathrm{H}_{36} \mathrm{~N}_{4} \mathrm{NiO}_{9}: \mathrm{C}, 58.06 ; \mathrm{H}$, 5.16; N, 7.97; Found: C, 58.01; H, 4.91; N, 7.91; ${ }^{1} \mathrm{H}$ NMR (400.13 MHz, $\left.\mathrm{CDCl}_{3}\right): \delta 1.169$ (t, 3H, $\mathrm{Me}, J=7.1 \mathrm{~Hz}$ ); 1.170 (bs, 9H, $t \mathrm{Bu}$ ); 1.20 (t, $3 \mathrm{H}, \mathrm{Me}, J=7.1 \mathrm{~Hz}$ ); 2.7 and 3.12 (AB part of ABX system, $\left.2 \mathrm{H}, \mathrm{CH}_{2}, J_{\mathrm{AB}}=15.2 \mathrm{~Hz}, J_{\mathrm{AX}}=3.9 \mathrm{~Hz}, J_{\mathrm{BX}}=6.3 \mathrm{~Hz}\right) ; 4.07-4.29\left(\mathrm{~m}, 5 \mathrm{H}, \mathrm{CH}, 2 \mathrm{CH}_{2}\right) ; 6.72$ $(\mathrm{m}, 2 \mathrm{H}, \mathrm{ArH}) ; 7.17(\mathrm{~d}, 1 \mathrm{H}, \mathrm{ArH}, J=6.4 \mathrm{~Hz}) ; 7.3(\mathrm{~m}, 2 \mathrm{H}, \mathrm{ArH}) ; 7.49$ (m, 3H, ArH); $7.91(\mathrm{~d}, 1 \mathrm{H}$, ArH, $J=7.8 \mathrm{~Hz}) ; 8.01(\mathrm{t}, 1 \mathrm{H}, \operatorname{ArH}, J=7.8 \mathrm{~Hz}) ; 8.17$ (d, 1H, ArH (CH-29), $J=5.3 \mathrm{~Hz}) ; 9.06(\mathrm{~d}$, $1 \mathrm{H}, \mathrm{ArH}(\mathrm{CH}-14), J=8.9 \mathrm{~Hz}) ;{ }^{13} \mathrm{C} \mathrm{NMR}\left(400.13 \mathrm{MHz}, \mathrm{CDCl}_{3}\right): \delta 13.67\left(\mathrm{CH}_{3}\right) ; 13.89\left(\mathrm{CH}_{3}\right) ; 27.75$ $\left(3 \mathrm{CH}_{3}\right) ; 35.13\left(\mathrm{CH}_{2}\right) ; 62.52\left(\mathrm{CH}_{2} \mathrm{CH}_{3}\right) ; 63.13\left(\mathrm{CH}_{2} \mathrm{CH}_{3}\right) ; 64.75(\mathrm{C}) ; 68.38\left(\mathrm{CHCH}_{2}\right) ; 80.62$ $(\mathrm{C}(\mathrm{tBu})) ; 121.28(\mathrm{C}-16) ; 123.52(\mathrm{C}-17) ; 124.03(\mathrm{C}-14) ; 126.60(\mathrm{C}-11) ; 126.65 ; 126.72(\mathrm{C}-15)$; $128.68 ; 128.89 ; 129.33 ; 129.76 ; 133.40 ; 133.66$ (C-18); 134.68; 140.41; 143.51 (C-13); 146.85 (C29); 153.60 (C-25); 154.62; 167.50; 167.67; 169.79; 172.51; 177.87; IR, (v/ $\left.\mathrm{cm}^{-1} ; \mathrm{KBr}\right): 1668 ; 1634$; $1604 ; 1592 ; 1714,1739,1762 ; 1744 ; 3406(\mathrm{NH})$.

1.4.4. Synthesis of Ni(II) complex $5 \mathrm{~d}$ of a Schiff base of PBP and ( \pm )2-amino-3-phenylsulfanylpropionic acid. The experiment was conducted similar to the one described in section 1.4.1., starting from $1(1.5 \mathrm{~g}, 3.5 \mathrm{mmol})$ in $\mathrm{CH}_{2} \mathrm{Cl}_{2}(15 \mathrm{ml})$, using $\mathrm{NaH}(0.014 \mathrm{~g} 0.35 \mathrm{mmol})$ as a base and thiophenol $(1 \mathrm{~g}, 9 \mathrm{mmol})$. The reaction was over within $25 \mathrm{~min}$ at $\mathrm{rt}$. The product was purified by chromatography on $\mathrm{SiO}_{2}$ column $\left(\mathrm{CHCl}_{3} / \mathrm{Me}_{2} \mathrm{CO}, 5 / 1\right)$. Yield of $\mathbf{5 d}$ was $75 \%$ (1.43g, 2.65mmol): mp $230-235^{\circ} \mathrm{C}$. Anal. Calcd. for $\mathrm{C}_{28} \mathrm{H}_{21} \mathrm{~N}_{3} \mathrm{NiO}_{3} \mathrm{~S} 0.5 \mathrm{H}_{2} \mathrm{O}$ : C, 61.45; H, 4.05; N, 7.68; Found: $\mathrm{C}$, 61.81; H, 3.70; N, 7.48; ${ }^{1} \mathrm{H}$ NMR (400.13 MHz, $\mathrm{CDCl}_{3}$ ): $\delta 2.95$ and 3.40 (AB part of ABX system, $\left.2 \mathrm{H}, \mathrm{CH}_{2}, J_{\mathrm{AB}}=14.2 \mathrm{~Hz}\right) ; 4.37\left(\mathrm{X}\right.$ part of ABX system, $\left.1 \mathrm{H}, J_{\mathrm{AX}}=6.4 \mathrm{~Hz}, J_{\mathrm{BX}}=2.2 \mathrm{~Hz}\right) ; 6.72(\mathrm{~m}$, $2 \mathrm{H}, \mathrm{ArH}) ; 6.80$ (d, 1H, $\operatorname{ArH}(\mathrm{CH}-16), J=7.4 \mathrm{~Hz}) ; 7.07$ (m, 3H, $\mathrm{ArH}) ; 7.25$ (m, 1H, ArH); 7.34-7.45 (m, 3H, ArH); 7.52 (m, 4H, ArH); 7.9 (d, 1H, ArH, $J=7.48 \mathrm{~Hz}) ; 8.0$ (t, 1H, ArH, $J=14.6 \mathrm{~Hz}) ; 8.09$ $(\mathrm{d}, 1 \mathrm{H}, \mathrm{ArH}(\mathrm{CH}-29), J=6.4 \mathrm{~Hz}) ; 8.96(\mathrm{~d}, 1 \mathrm{H}, \mathrm{ArH}(\mathrm{CH}-14), J=8.5 \mathrm{~Hz}) ;{ }^{13} \mathrm{C}$ NMR $(300.13 \mathrm{MHz}$, $\left.\mathrm{CDCl}_{3}\right)$ : $\delta 37.91\left(\mathrm{CH}_{2}\right) ; 70.55(\mathrm{CH}) ; 121.31(\mathrm{C}-16) ; 123.61(\mathrm{C}-17) ; 124.05(\mathrm{C}-14) ; 126.86(\mathrm{C}-15)$; $126.91 ; 126.97 ; 127.72 ; 128.86 ; 129.27 ; 130.05 ; 131.22 ; 133.65 ; 133.98 ; 134.56 ; 140.36 ; 143.60$; $147.14 ; 165.27 ; 170.02 ; 172.86 ; 176.39 ;$ IR, $\left(v / \mathrm{cm}^{-1} ; \mathrm{KBr}\right): 1672 ; 1642 ; 1606 ; 1592$.

\subsubsection{Synthesis of Ni(II) complex 5e of a Schiff's base of PBP and ( \pm )2-amino-3-indol-1-yl-} propionic acid. The reaction was conducted in $15 \mathrm{ml} \mathrm{CH} \mathrm{CH}_{3} \mathrm{CN}$ starting from complex $\mathbf{1}(1.5 \mathrm{~g}$, $3.5 \mathrm{mmol})$, indole $(0.63 \mathrm{~g}, 4.2 \mathrm{mmol})$ and $\mathrm{NaH}(0.035 \mathrm{~g}, 0.875 \mathrm{mmol})$. The reaction time was $2.5-3 \mathrm{~h}$ at $80{ }^{\circ} \mathrm{C}$. To the reaction mixture was added $10 \%$ aq. $\mathrm{AcOH}$, then it was quenched by adding $200 \mathrm{ml}$ water. After $1 \mathrm{~h}$ the precipitate was filtered and washed with water and dried at air After purification by column chromatography $\left(\mathrm{CHCl}_{3}: \mathrm{MeCOMe}=8: 1\right)$ the yield of pure 5e was $80 \%(1.5 \mathrm{~g}, 2.8$ mmol): mp 290-292 ${ }^{\circ} \mathrm{C}$. Anal. Calcd. for $\mathrm{C}_{30} \mathrm{H}_{22} \mathrm{~N}_{4} \mathrm{NiO}_{3} 0.25 \mathrm{CHCl}_{3}$ : C, 63.18; H, 3.90; N, 9.74; Found: 63.46; H, 3.77; N, 9.70; ${ }^{1} \mathrm{H}$ NMR $\left(400.13 \mathrm{MHz}, \mathrm{CDCl}_{3}\right)$ : $\delta 4.35-4.41\left(\mathrm{~m}, 2 \mathrm{H}, \mathrm{CH}_{2}\right) ; 4.76$ $(\mathrm{m}, 1 \mathrm{H}, \mathrm{CH}) ; 6.4$ (d, 1H, Ind-3, $J=3.2 \mathrm{~Hz}) ; 6.77-6.87$ (m, 3H, ArH); 7.01-7.1 (m, 2H, ArH); 7.137-17 (m, 2H, ArH); 7.24 (d, 1H, Ind-2, J = 3.2 Hz); 7.29 (m, 1H, ArH); 7.36 (m, 2H, ArH); 7.41-7.5 (m, 2H, ArH);7.57 (m, 2H, ArH); $7.68(\mathrm{~d}, 1 \mathrm{H}, \mathrm{ArH}, J=7.4 \mathrm{~Hz}) ; 7.86(\mathrm{t}, 1 \mathrm{H}, \mathrm{ArH}, J=7.4 \mathrm{~Hz}) ; 8.8$ $(\mathrm{d}, 1 \mathrm{H}, \operatorname{ArH}(\mathrm{CH}-14), J=8.9 \mathrm{~Hz}) ;{ }^{13} \mathrm{C}$ NMR $\left(400.13 \mathrm{MHz}, \mathrm{CDCl}_{3}\right): \delta 50.27\left(\mathrm{CH}_{2}\right) ; 72.27(\mathrm{CH})$; 102.62 (C-3, Ind); 110.64 (C-7, Ind); 120.12; 120.45; 121.39; 121.93; 123.59; 123.87; 126.51 (C-2, 
Ind); 126.68 (C-11); 127.26; 127.37; 129.09 (C-9, Ind); 129.39; 129.59; 130.27; 133.44; 133.86; 134.59; 137.23 (C-8, Ind); 139.76; 143.64 (C-13); 146.33 (C-29); 152.79 (C-25); 169.40; 172.37; 177.25; IR, (v/cm ${ }^{-1}$; KBr): 1668; 1639; 1609, 1589.

1.4.6. Synthesis of $\mathrm{Ni}(\mathrm{II})$ complex $5 \mathrm{f}$ of a Schiff base of PBP and ( \pm )2-amino-3-imidazol-1-ylpropionic acid. The reaction was conducted in $15 \mathrm{ml} \mathrm{CH}_{3} \mathrm{CN}$ starting from complex $1(1.5 \mathrm{~g}, 3.5$ mmol) imidazole $(0.47 \mathrm{~g}, 7 \mathrm{mmol})$ and $\mathrm{NaH}(0.03 \mathrm{~g}, 0.75 \mathrm{mmol})$. The reaction time was $1.5 \mathrm{~h}$ at $80^{\circ} \mathrm{C}$. To the reaction mixture was added $10 \%$ aq. $\mathrm{AcOH}$, then it was quenched by adding $200 \mathrm{ml}$ water. After $1 \mathrm{~h}$ the precipitate was filtered and washed with water and dried at air After purification by column chromatography $\left(\mathrm{CHCl}_{3}: \mathrm{MeCOMe}: \mathrm{MeOH}=5 / 1 / 3\right)$ the yield of pure $\mathbf{5 f}$ was $83.5 \%(1.45 \mathrm{~g}$, 2.92mmol): $\mathrm{mp} 236-238{ }^{\circ} \mathrm{C}$ (decomp). Anal. Calcd. for $\mathrm{C}_{25} \mathrm{H}_{19} \mathrm{~N}_{5} \mathrm{NiO}_{3}$ : C, 60.52; H, 3.86; N, 14.12; Found: C, 60.88; H, 3.52; N, 14.47; ${ }^{1} \mathrm{H} \mathrm{NMR}\left(300.13 \mathrm{MHz}, \mathrm{CDCl}_{3}, \mathrm{~T}=330 \mathrm{~K}\right): \delta 4.01$ and $4.06(\mathrm{AB}$ part of $\mathrm{ABX}$ system, $\left.2 \mathrm{H}, \mathrm{CH}_{2}, J_{\mathrm{AB}}=14.4 \mathrm{~Hz}, J_{\mathrm{AX}}=4.0 \mathrm{~Hz}, J_{\mathrm{BX}}=2.8 \mathrm{~Hz}\right) ; 4.73(\mathrm{bs}, 1 \mathrm{H}, \mathrm{CH}) ; 6.72$ $(\mathrm{t}, 1 \mathrm{H}, \operatorname{ArH}(\mathrm{CH}-16), J=7.3 \mathrm{~Hz}) ; 6.87(\mathrm{dd}, 1 \mathrm{H}, \operatorname{ArH}(\mathrm{CH}-17), J=8.2 \mathrm{~Hz}, J=1.6 \mathrm{~Hz}) ; 7.07$ (bs, $1 \mathrm{H}$, ArH); 7.15 (bs, 1H, imidazol-5); 7.33 (bs, 1H, imidazol-4); 7.40-7.51 (m, 3H, ArH); 7.58 (m, 3H, ArH); 7.82 (bs, 1H, imidazol-2); 7.92 (t, 1H, ArH, J=7.5 Hz); 8.02 (d, 1H, ArH (CH-29), J=7.3 $\mathrm{Hz}) ; 8.4$ (bs, $1 \mathrm{H}, \mathrm{ArH}) ; 8.8(\mathrm{~d}, 1 \mathrm{H}, \operatorname{ArH}(\mathrm{CH}-14), J=8.7 \mathrm{~Hz}) ;{ }^{13} \mathrm{C} \mathrm{NMR}\left(300.13 \mathrm{MHz}, \mathrm{CDCl}_{3}, \mathrm{~T}=\right.$ 330K): $\delta 50.45\left(\mathrm{CH}_{2}\right) ; 71.16(\mathrm{CH}) ; 121.67 ; 122.55$ (imidazol-4); 124.42; 125.97; 126.71; 127.33; $128.41 ; 129.33 ; 129.81 ; 130.16$ (imidazol 5); 130.44; 134.00; 134.20; 136.52; 139.91 (imidazol-2); 140.54; 143.73 (C-13); 146.93 (C-29); 152.03 (C-25); 168.60; 173.39; 175.28; IR, (v/cm ${ }^{-1}$ KBr): $1676 ; 1628 ; 1605,1587$.

\subsubsection{Synthesis of $\mathrm{Ni}(\mathrm{II})$ complex $5 \mathrm{~g}$ of a Schiff base of PBP and ( \pm )-2-amino-3-benzylamino-} propionic acid. To the complex $1(1.5 \mathrm{~g}, 3.51 \mathrm{mmol})$ in $\mathrm{CH}_{2} \mathrm{Cl}_{2}(10 \mathrm{ml})$ under $\mathrm{Ar}$ were added $\mathrm{C}_{6} \mathrm{H}_{5} \mathrm{CH}_{2} \mathrm{NH}_{2}(1.2 \mathrm{ml}, 10.54 \mathrm{mmol})$ and $\mathrm{NaH}(0.014 \mathrm{~g}, 0.351 \mathrm{mmol})$. The mixture was stirred at r.t. for $1 \mathrm{~h}$ until disappearance of the initial complex. The course of the reaction was monitored by TLC $\left(\mathrm{CHCl}_{3}: \mathrm{CH}_{3} \mathrm{COCH}_{3}=5: 1\right)$. Then the reaction mixture was quenched with $10 \%$ aq AcOH. The precipitate was filtered by dense filter, washed with water several times, dried at air and giving $\mathbf{5 g}$ with yield 1,1g (2.06mmol, $58 \%$ ). For getting pure sample for analyses the product was crystallized from $\mathrm{CH}_{3} \mathrm{Cl} /$ Hexane: mp 176-178 ${ }^{\circ} \mathrm{C}$. Anal. Calcd. for $\mathrm{C}_{29} \mathrm{H}_{24} \mathrm{~N}_{4} \mathrm{NiO}_{3} 0.125 \mathrm{CHCl}_{3} \mathrm{C}, 63.59 ; \mathrm{H}$, 4.42; N, 10.18; Found: C, 63.73; H, 4.25; N, 9.8; ${ }^{1} \mathrm{H}$ NMR (400.13 MHz, $\left.\mathrm{CDCl}_{3}\right): \delta 2.04$ (bs, $1 \mathrm{H}$, $\mathrm{NH}) ; 2.92-3.02\left(\mathrm{~m}, 2 \mathrm{H}, \mathrm{CH}_{2}\right) ; 3.72\left(\mathrm{AB}\right.$ system $\left.2 \mathrm{H}, \mathrm{CH}_{2}, J_{\mathrm{AB}}=13.5 \mathrm{~Hz}\right) ; 4.06(\mathrm{~m}, 1 \mathrm{H}, \mathrm{CH}) ; 6.42(\mathrm{~d}$, $1 \mathrm{H}, \operatorname{ArH}, J=7.4 \mathrm{~Hz}) ; 6.74(\mathrm{~m}, 2 \mathrm{H}, \mathrm{ArH}) ; 7.09(\mathrm{~m}, 3 \mathrm{H}) ; 7.23-7.48$ (m, 8H, ArH); $7.90(\mathrm{~m}, 1 \mathrm{H}$, $\operatorname{ArH}) ; 7.97$ (m, 1H, ArH); 8.2 (d, 1H, ArH (CH-29), J = 5,2 Hz); 8.96 (d, 1H, ArH(CH-14), J = 8.7 $\mathrm{Hz}) ;{ }^{13} \mathrm{C}$ NMR $\left(400.13 \mathrm{MHz}, \mathrm{CDCl}_{3}\right): \delta 52.15\left(\mathrm{CH}_{2}\right) ; 52.86\left(\mathrm{CH}_{2}\right) ; 71.09(\mathrm{CH}) ; 121.29 ; 123.51$; $124.05 ; 127.78 ; 126.86 ; 127.01 ; 127.99 ; 128.07 ; 128.18 ; 128.75 ; 129.00 ; 129.68 ; 133.29 ; 133.79$ (C-18); 134.41; 140.08; 140.37; 143.25 (C-13); 147.00 (C-29); 153.49 (C-25); 169.95; 171.81; 178.84; IR, (v/cm-1; KBr): 1668; 1644; 1606; 1591; 1587; $3321(\mathrm{NH})$.

1.4.8. Synthesis of Ni(II) complex $5 \mathrm{~h}$ of a Schiff base of PBP and ( \pm )2-amino-3-(naphthalen-2-

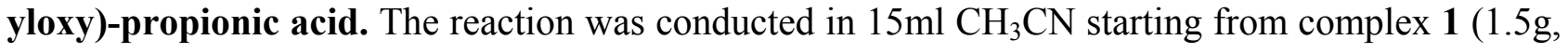
$3.5 \mathrm{mmol})$ 2-naphtol $(0.6 \mathrm{~g}, 4.2 \mathrm{mmol})$ and $\mathrm{NaH}(0.07 \mathrm{~g}, 1.75 \mathrm{mmol})$. The reaction time was $2 \mathrm{~h}$ at $80^{\circ} \mathrm{C}$. To the reaction mixture was added $10 \%$ aq. $\mathrm{AcOH}$, then it was quenched by adding $200 \mathrm{ml}$ water. After $1 \mathrm{~h}$ the precipitate was filtered and washed with water and dried at air After purification 
by column chromatography $\left(\mathrm{CHCl}_{3}: \mathrm{MeCOMe}=5: 1\right)$ the yield of pure product was $84 \%(1.68 \mathrm{~g}$, 2.94mmol): $\mathrm{mp} 289-292{ }^{\circ} \mathrm{C}$. Anal. Calcd. for $\mathrm{C}_{32} \mathrm{H}_{23} \mathrm{~N}_{3} \mathrm{NiO}_{4}: \mathrm{C}, 67.17 ; \mathrm{H}, 4.05 ; \mathrm{N}, 7.34$; Found: $\mathrm{C}$, 66.91; H, 3.84; N, 7.19; ${ }^{1} \mathrm{H}$ NMR (300.13 MHz, $\left.\mathrm{CDCl}_{3}\right): \delta 3.40\left(\mathrm{~m}, 1 \mathrm{H}, \mathrm{CH}_{2}\right) ; 3.72\left(\mathrm{~m}, 1 \mathrm{H}, \mathrm{CH}_{2}\right)$; $4.02(\mathrm{~m}, 1 \mathrm{H}, \mathrm{CH}) ; 6.68(\mathrm{~d}, 1 \mathrm{H}, J=8.3 \mathrm{~Hz}) ; 6.84(\mathrm{~m}, 2 \mathrm{H}, \mathrm{ArH}) ; 7.04$ and 7.29 (AB system, 2H, Naph-3, Naph-4, J = 8.8 Hz); 7.07-7.26 (m, 3H, ArH); 7.32-7.38 (m, 3H, ArH); 7.49-7.65 (m, 5H, $\operatorname{ArH}) ; 7.69$ (d, 1H, ArH, $J=7.6 \mathrm{~Hz}) ; 8.07$ (t, 1H, ArH, J = 7.3Hz); 8.75 (d, 1H, ArH, J = 8.52 Hz); $9.89(\mathrm{~s}, 1 \mathrm{H}, \mathrm{OH}) ;{ }^{13} \mathrm{C}$ NMR $\left(300.13 \mathrm{MHz}, \mathrm{DMSO}_{6}\right): \delta 28.80\left(\mathrm{CH}_{2}\right) ; 71.68(\mathrm{CH}) ; 113.76$ (Naph1); 117.44 (Naph-3); 121.02; 121.83; 123.00;123.08; 123.40;125.72; 127.31; 127.59; 127.91; $127.94 ; 128.04 ; 128.36 ; 128.56 ; 128.92 ; 129.07 ; 129.76 ; 132.45 ; 133.50 ; 133.84 ; 134.63 ; 140.82$; 143.15; 145.43; 152.08 (C-25); 154.96 (Naph-2); 168.73; 170.64; 177.05; IR, (v/cm ${ }^{-1}$; KBr): 1680; $1624 ; 1603 ; 1592 ; 3325(\mathrm{OH})$.

1.4.9. Synthesis of $\mathrm{Ni}(\mathrm{II})$ complex $5 \mathrm{i}$ of a Schiff base of $P B P$ and $( \pm)-2,4$ diamino-pentanedioic acid 5i. To the suspension of $1(4 \mathrm{~g}, 9.37 \mathrm{mmol})$ in $\mathrm{CH}_{3} \mathrm{CN}(40 \mathrm{ml})$ under Ar were added $\mathrm{C}_{6} \mathrm{H}_{5} \mathrm{OH}$ $(1.04 \mathrm{~g}, 11.05 \mathrm{mmol})$ and $\mathrm{NaH}(0.372 \mathrm{~g}, 9.3 \mathrm{mmol})$. The reaction time was $2 \mathrm{~h}$ at $80{ }^{0} \mathrm{C}$. The course of the reaction was monitored by TLC $\left(\mathrm{CHCl}_{3}: \mathrm{CH}_{3} \mathrm{COCH}_{3}=5: 1\right)$. In accordance to TLC besides the main product there were many byproducts in the reaction mixture. To the reaction mixture was added $10 \%$ aq. $\mathrm{AcOH}$, then it was quenched by adding $700 \mathrm{ml}$ water. In $1 \mathrm{~h}$ the precipitate was filtered washed with water and dried at air After purification by column chromatography $\left(\mathrm{CHCl}_{3}: \mathrm{MeCOMe}=5: 1\right)$ the main product was washed with acetone, filtered by dense filter and dried giving $25 \%$ pure $5 \mathbf{i}(1.0 \mathrm{~g}, 1.18 \mathrm{mmol})$. For analyses the product was crystallized from $\mathrm{MeOH} / \mathrm{CHCl}_{3}$ : mp 298-300 ${ }^{\circ} \mathrm{C}$ (decomp). Anal. Calcd. for $\mathrm{C}_{43} \mathrm{H}_{30} \mathrm{~N}_{6} \mathrm{Ni}_{2} \mathrm{O}_{6} 0.33 \mathrm{H}_{2} \mathrm{O}: \mathrm{C}, 60.75 ; \mathrm{H}$, 3.64; N, 9.89; Found: C, 60.48; H, 3.29; N, 9.62; ${ }^{1} \mathrm{H}$ NMR (300.13 MHz, $\left.\mathrm{CDCl}_{3}\right): \delta 2.01(\mathrm{t}, J=4.4$ $\left.\mathrm{Hz}, 2 \mathrm{H}, \mathrm{CH}_{2}\right) ; 4.15$ (t, 2H, 2CH, J=4.4 Hz,); 6.86 (t, 2H, $\left.\mathrm{ArH}(\mathrm{CH}-16), J=7.5 \mathrm{~Hz}\right) ; 7.05$ (dd, 2H, $\operatorname{ArH}(\mathrm{CH}-17), J=8.3 \mathrm{~Hz}, J=1.4 \mathrm{~Hz}) ; 7.25(\mathrm{~m}, 2 \mathrm{H}, \mathrm{ArH}) ; 7.30-7.45$ (m, 12H, ArH); 7.81 (t, 4H, $\operatorname{ArH}, J=7.4 \mathrm{~Hz}) ; 8.2$ (d, 2H, $\mathrm{ArH}(\mathrm{CH}-29), J=5,2 \mathrm{~Hz}) ; 8.91$ (d, 2H, $\mathrm{ArH}(\mathrm{CH}-14), J=8.56 \mathrm{~Hz}) ;{ }^{13} \mathrm{C}$ NMR (300.13MHz, $\left.\mathrm{CDCl}_{3}\right): \delta 35.25\left(\mathrm{CH}_{2}\right) ; 68.28(\mathrm{CH}) ; 122.07(\mathrm{C}-16) ; 123.28(\mathrm{C}-17) ; 123.84(\mathrm{C}-$ 14); 126.02; 126.98 (C-15); 127.02 (C-11); 128.38; 128.86; 129.67; 130.19; 133.73; 134.49 (C-18); 135.44; 140.02 ; 142.76 (C-13); 147.46 (C-29); 152.55 (C-25); 170.09 (C-24); 177.47 (C-12); 179.61 (COO); IR, ( $/ \mathrm{cm}^{-1}$; KBr): ): 1668; 1644; 1606; 1591; 1587; 1327.

\subsection{Methods of recovery and analytical data of chiral and achiral amino acids}

1.5.1. (S)-2-Amino-pentanedioic acid (6a). The complex (S)-5a 1.08g (1.84mmol) was decomposed by refluxing its suspension in a mixture of aq. $6 \mathrm{~N} \mathrm{HCl}(5 \mathrm{ml})$ and $\mathrm{MeOH}(6 \mathrm{ml})$ for $2 \mathrm{~h}$, then the solution was evaporated to dryness. Water was added to the residue and the insoluble material was filtered off, washed with water and dried to afford hydrochloride of PBP. The $\mathrm{pH}$ of the aqueous layer was adjusted to 7 using aqueous ammonia solution and the mixture was extracted with $\mathrm{CHCl}_{3}(3 \times 10 \mathrm{ml})$ to remove small amounts of remaining PBP. The amino acid was recovered from the aq. solution by the ion-exchange technique (DOWEX-50, $\mathrm{H}^{+}$form). The amino acid was crystallized from EtOH/water with yielding $0.17 \mathrm{~g}(1.156 \mathrm{mmol}, 63 \%)$ 6a (ee 92\%).

1.5.2. 2-Amino-3-phenylsulfanyl-propionic acid (6d). ${ }^{15}$ A mixture of $\mathbf{5 d}(1.4 \mathrm{~g}, 2.6 \mathrm{mmol}), 10 \mathrm{ml}$ $\mathrm{MeOH}$ and $6 \mathrm{~N} \mathrm{HCl}$ was refluxed $20 \mathrm{~min}$, and then evaporated to dryness. Water $(10 \mathrm{ml})$ was added to the residue and the insoluble material filtered, washed with water and dried to afford ligand. To 
the water solution conc. aqueous ammonia solution is added to bring the $\mathrm{pH}$ of the solution to 9-10, followed by ETDA $(0.87 \mathrm{~g}, 2.6 \mathrm{mmol})$ and $10 \mathrm{ml}$ of benzene. The mixture was stirred for $1 \mathrm{~h}$ and then the water layer was separated and concentrated. The precipitate was filtered and washed with aq ETDA solution and water and finally recrystallized from $1 \mathrm{~N} \mathrm{HCl}$ giving $6 \mathbf{d}$ with $61 \%$ yield: mp $200^{0}$ C. Anal. Calcd. for . $\mathrm{C}_{9} \mathrm{H}_{11} \mathrm{NO}_{2} \mathrm{~S} \cdot 0.05 \mathrm{HCl}$ : C, 54.30; H, 5.59; N, 7.04; Found: C, 54.1; H, 5.57, $\mathrm{N}, 7.2$.

1.5.3. 2-Amino-3-indol-1-yl-propionic acid (6e). The complex 5e 1.5g, (2.8 mmol) was decomposed by refluxing its suspension in a mixture of aq. $6 \mathrm{~N} \mathrm{HCl}(10 \mathrm{ml})$ and $\mathrm{MeOH}(7 \mathrm{ml})$ for 40min, then the solution was evaporated to dryness. Water was added to the residue and the insoluble material was filtered off, washed with water and dried to afford hydrochloride PBP. The $\mathrm{pH}$ of the aqueous layer was adjusted to 7 using aqueous ammonia solution and the mixture was extracted with $\mathrm{CHCl}_{3}(3 \times 10 \mathrm{ml})$ to remove small amounts of remaining PBP. The amino acid was recovered from the aq. solution by ion-exchange technique (DOWEX-50, $\mathrm{H}^{+}$form). The amino acid was crystallized from EtOH/water yielding 0.3g (1.47mmol, 52\%) 6e: mp 218-220 ${ }^{0} \mathrm{C}$. Anal. Calcd. for $\mathrm{C}_{11} \mathrm{H}_{12} \mathrm{~N}_{2} \mathrm{O}_{2} 0.57 \mathrm{HCl}$ : C, 58,70; H, 5,63; N, 12,45; Found: C, 58.54; H, 5.32; N, 12.31. ${ }^{1} \mathrm{H}$ NMR: (400.13 MHz, DMSO-D $)$ ) $\delta 3.62(\mathrm{~m}, 1 \mathrm{H}, \mathrm{CH}) ; 4.35\left(\mathrm{~m}, 1 \mathrm{H}, \mathrm{CH}_{2}\right) ; 4.62\left(\mathrm{~m}, 1 \mathrm{H}, \mathrm{CH}_{2}\right) ; 6.43$ $(\mathrm{d}, 1 \mathrm{H}$, Ind-3, $J=3.1 \mathrm{~Hz}) ; 7.02(\mathrm{t}, 1 \mathrm{H}$, Ind,$J=7.2 \mathrm{~Hz}) ; 7.14$ (t, 1H, Ind, $J=7.4 \mathrm{~Hz}) ; 7.37$ (d, 1H, Ind-2, $J=3.0 \mathrm{~Hz}) ; 7.53\left(\mathrm{~m}, 2 \mathrm{H}\right.$, Ind); ${ }^{13} \mathrm{C}$ NMR (400.13 MHz, DMSO-D $): \delta 48.53\left(\mathrm{CH}_{2}\right) ; 55.89$ (CH); 102.31 (Ind-3); 111.07 (Ind-7); 120.32 (Ind-6); 121.53 (Ind-4); 122.33 (Ind-5); 129.57 (Ind9); 130.40 (Ind-2); 137.23 (Ind-8); 169.20 (COO)

1.5.4. 2-Amino-3-(naphthalen-2-yloxy)-propionic acid (6h). To a solution of $\mathbf{5 h}(1.68 \mathrm{~g}$, $2.94 \mathrm{mmol})$ in $10 \mathrm{ml}$ of $\mathrm{MeOH}$ was added $6 \mathrm{~N} \mathrm{HCl}(10 \mathrm{ml})$ with stirring at reflux for 40 minutes. Then the solvent was evaporated and water was added to the solution. The $\mathrm{pH}$ of the aqueous solution was adjusted to 8 by aqueous ammonia and the ligand was extracted with $\mathrm{CH}_{2} \mathrm{Cl}_{2}$. The insoluble amino acid was filtered off to give $0.4 \mathrm{~g} \mathbf{6 h}(1.73 \mathrm{mmol}, 58 \%)$. The amino acid was crystallized from $3 \mathrm{~N} \mathrm{HCl}$ yielding $0.3 \mathrm{~g} \quad(1.47 \mathrm{mmol}, 52 \%) \quad \mathbf{6 h}: \mathrm{mp} 249^{0} \mathrm{C}$ (decomp). Anal. Calcd. for $\mathrm{C}_{13} \mathrm{H}_{14} \mathrm{ClNO}_{3} .0 .66 \mathrm{H}_{2} \mathrm{O}$ : C, 55.70; H, 5.53; N, 4.93;. Found: C, 55.41; H, 5.84; N, 5.01. ${ }^{1} \mathrm{H}$ NMR: (400.13 MHz, DMSO-D 6 ): $\delta 3.40$ and 3.55 (AB part of $\mathrm{ABX}$ system, $2 \mathrm{H}, \mathrm{CH}_{2}, J_{\mathrm{AB}}=14.0 \mathrm{~Hz}$ ); 3.85 (X part $\mathrm{ABX}$ of system, $1 \mathrm{H}, \mathrm{CH}, J_{\mathrm{AX}}=6.2 \mathrm{~Hz}, J_{\mathrm{BX}}=8.6 \mathrm{~Hz}$ ); 7.44 (AB system, 2H, Naph-3, Naph4), $J=9.0 \mathrm{~Hz}) ; 7.29$ (t, 1H, Naph-6, $J=7.2 \mathrm{~Hz}$ ); 7.46 (t, 1H, Naph-7, $J=7.2 \mathrm{~Hz}) ; 7.79$ (d, 1H, naph-5, $J=8.1 \mathrm{~Hz}) ; 7.98(\mathrm{~d}, 1 \mathrm{H}, \mathrm{Naph}-8, J=8.4 \mathrm{~Hz}) ;{ }^{13} \mathrm{C}$ NMR $\left(400.13 \mathrm{MHz}, \mathrm{DMSO}-\mathrm{D}_{6}\right): \delta 27.70$ $\left(\mathrm{CH}_{2}\right) ; 59.97$ (CH); 114.72 (Naph-1); 119.71 (Naph-3); 123.42 (Naph); 123.48 (Naph); 127.60 (Naph); 129.36 (Naph-10); 129.69(Naph); 129.74 (Naph); 134.44 (Naph-9); 155.14 (Naph-2); 171.85 (COO).

\section{Supporting information is available}

http://www.arkat-usa.org/ark/journal/2004/I03_Makosza/MM-853G/853Gsupportinginfo.pdf 


\section{Acknowledgments}

The work was supported by Swiss grant SCOPES (Project № 7SUPJ62125) and also by Russian Foundation for Basic Research (Project № 02-03-32050). Authors thank Dr Ikonnikov N.S. for conducting GLC asymmetric analyses.

\section{References}

1. (a) Krause N.; Hoffmann-Röder A. Synthesis 2001, 2, 171. (b) Joshi, N. N.; Jha, S. C.; ARKIVOC 2002, (vii), 167. (c) McDaid, P.; Chen, Y.; Deng, L. Angew .Chem., Int Ed. 2002, 41, 338. (d) M. Jamaguchi, T. Shiraishi, and M. Hirama, J. Org. Chem. 1996, 61, 3520. (e) Halland, N.; Hazell, R. G.; Jorgensen, K. A. J. Org. Chem. 2002, 67, 8331.

2. (a) Corey, E. L.; Noe, M. C.; Xu, F. Tetrahedron Lett. 1998, 39, 5347. (b) Shibuguchi, T.; Fukuta, Y.; Sekine, A.; Ohschima, T.; Shibasaki, M. Tetrahedron Lett. 2002, 43, 9539.

3. Lygo, B.; Crosby, J.; Lowdon, T. R.; Peterson, J. A.; Wainwright, P. G. Tetrahedron 2001, 57, 2403.

4. (a) Pracejus H.; Wilke F.-W.; Hanemann K. J. Prakt .Chem. 1977, 319, 219. (b) Kumar A.; Salunkhe R. V.; Rane R. A.; Dike S. Y. J. Chem. Soc., Chem. Commun. 1991, 485. (c) Emori, E.; Arai, T.; Sasai, H.; Shibasaki, M. J. Am. Chem. Soc. 1998, 120, 4043.

5. (a) Fehr C. Angew. Chem., Int. Ed. 1996, 35, 2566. (b) Yanagisawa A.; Yamamoto H. In Comprehensive Asymmetric Catalysis; Jacobsen, E. N. A.; Pflatz, A.; Yamamoto, H., Eds.; Springer: Heidelberg, 1999; pp 1295. (c) Fehr C.; Stempf I.; Galindo J. Angew. Chem., Int. Ed. 1993, 32, 1042. (d) Yanagisawa A; Watanabe T.; Kikuchi T.; Yamamoto H. J. Org. Chem. 2000, 65, 2979. (e) Munoz-Muniz O.; Juaristi E. Tetrahedron Lett. 2003, 44, 2023. (f) Nishimura K.; Ono M.; Nagaoka Y.; Tomioka K. Angew. Chem. Int. Ed. Engl. 2001, 40, 440.

6. Cox , P. J.; Simpkins N. S. Tetrahedron: Asymmetry 1991, 2, 1.

7. Cuenca, A.; Medio-Simon, M.; Aguilar G.; Weibel D.; Beck A. K.; Seebach D. Helv. Chim. Acta 2000, 83, 3153.

8. Belokon, Y.; Kochetkov, K.; Churkina, T.; Ikonnikov, N.; Chesnokov, A.; Larionov, O.; Singh, I.; Virinder; P. S.; Vyskocil, S.; Kagan, H. J. Org. Chem. 2000, 65, 7041.

9. Belokon, Y. N.; Kochetkov, K. A.; Churkina, T. D.; Ikonnikov, N. S.; Larionov, O. V.; Harutyunyan, S. R.; Nort, M.; Viscochil, S.; Kagan, H. Angew. Chem., Int. Ed. 2001, 40, 1948.

10. (a) Jim, A.; Vidal, Y.; Viallefont; M. J. Tetrahedron: Asymmetry 2002, 13, 503. (b) Alsamini, C.; Diamantini, G.; Duranti, A.; Spadoni, G.; Tontini, A. Synthesis 1994, 370. (c) Tarzia, G.; Balsamini, C.; Diamantini, G.; Duranti, A. Synthesis 1988, 370. (d) Gativela, C.; Lopes, P.; Majoral, J. A. Tetrahedron: Asymmetry 1991, 12, 1295. (e) Belokon' Y. N.; Sagyan, A. S.; Djamgaryan, S.; Bakhmutov, V. I.; Belikov, V. Tetrahedron 1988, 17, 5507. (f) Gasanov, R. G.; Ilinskaya, L. V.; Misharin, M. A.; Maleev, V. I.; Raevski, N. I.; Ikonnikov, N. S.; Kuzmina, S. A.; Belokon' Y. N. J. Chem. Soc., Perkin. Trans. 1 1994, 3343. 
11. Terekhova, M. I.; Belokon, Y. N.; Maleev, V. I;. Chernoglazova, N. I.; Kochetkov, K. A.; Belikov, V. M.; Petrov, E. S. Izv. Akad. Nauk SSSR, Ser. Khim. 1986, 905 [Bull Acad. Sci. USSR, Div. Chem. Sci. 1986, 35, 824 (Engl.Trans1.)].

12. Seebach, D., Beck, A. K.; Heckel, A. Angew. Chem., Int. Ed. 2001, 40, 92.

13. SMART and SAINT, Release 5.0. Area detector control and integration software. Bruker AXS, Analytical X-Ray Instruments, Madison, Wisconsin, USA, 1998.

14. Sheldrick, G. M. SHELXTL. V5.10. Bruker AXS Inc. Madison. WI-53719. USA. 1997.

15. Jpn. Kokai Tokkyo Koho (1998), 4 pp. CODEN: JKXXAF JP 10001468 A2 1998. 